\title{
A STUDY OF THE FLOWERING PLANTS OF TULSA COUNTY, OKLAHOMA, EXCLUSIVE OF THE GRASSES, SEDGES, AND RUSHES
}

\author{
Master's Thesis \\ University of Tulsa \\ Tulsa, Oklahoma \\ 1959
}

\section{Maxine B. Clark† \\ 1905-1988}

\author{
Keywords: riparian, prairie, limestone, flora, historical, ecology
}

\begin{abstract}
A taxonomic study of the flowering plants of Tulsa County, Oklahoma, exclusive of the grasses, sedges, and rushes, was made from 1955 to 1959. A total of 585 species, representing 99 families and 335 genera, were identified and are on file in the herbarium of the University of Tulsa. The largest families in order of number of species are: Compositae [Asteraceae], 110 species; Leguminosae [Fabaceae], 50 species; Euphorbiaceae, 22 species; Cruciferae [Brassicaceae], 21 species; Rosaceae, 19 species; Scrophulariaceae [Linderniaceae, Orobanchaceae, Phrymaceae, Plantaginaceae, Scrophulariaceae], 18 species; Labiateae [Lamiaceae], 16 species; Polygonaceae, 16 species; and Onagraceae, 15 species. The number of plants found is comparable to similar collections in Muskogee County by Little (1938) and in Pontotoc County by McCoy (1958). The plant list of Tulsa County may be increased by further study.

Editor's Note: Where nomenclature has been updated using ITIS-Integrated Taxonomic Information Service (http://www.itis.gov), the revised name is in brackets [ ], as are other updates.

\section{INTRODUCTION}

\section{Statement of Problem}

A taxonomic study of the flowering plants of Tulsa County, Oklahoma, exclusive of the grasses, sedges, and rushes, was initiated by the author in the spring of 1956. One hundred twenty-five plants were collected from April 21 through

November 7. Intensive field work began March 1, 1957, with 700 plants collected through November 17. Additional collections were made in 1958 and 1959. A total of 828 specimens were collected. Most plants were taken in triplicate for the herbaria of the University of Tulsa, the University of Oklahoma, and Oklahoma

State University. An attempt was made to collect all plants at anthesis, but fruiting specimens were also collected whenever possible. Classification of the oaks was not attempted without the acorns. All plants were identified and pressed by the author. A few additional specimens on file in the herbarium of the University of Tulsa have been included in the list of species. Classification of the plants was established through the use of all available manuals applicable to the area, through references in Rhodora, and comparison with specimens at the Bebb Herbarium at the University of Oklahoma and the herbarium of Oklahoma State University. Some plants, collected at flowering time, lacked diagnostic varietal
\end{abstract}


characteristics, and in such cases the variety name was omitted. Whenever possible, the nomenclature as given in Gray's Manual of Botany, $8^{\text {th }}$ ed., has been followed. In a few cases in which reference material was not available for the checking of varieties and only one variety was listed for Oklahoma, the varietal designations were taken from Waterfall (1952a).

\section{Physical Aspects of Tulsa County}

Tulsa County is located in northeastern Oklahoma (Figure 1). The northern border of the county is approximately $40 \mathrm{mi}$ [64.37 km] south of the Kansas line and its eastern border is about $70 \mathrm{mi}$ [112.65 km] west of the Arkansas line. The county has a total area of $593 \mathrm{mi}^{2}$ [1535.86 $\left.\mathrm{km}^{2}\right]$ and is included in Tps 16-22 N, Rs 10-14 E, Indian Meridian (Figure 2). It extends north and south $39 \mathrm{mi}[62.76 \mathrm{~km}]$ and east and west from 10.5-15 mi [16.9-24.14 km], exclusive of an arm $6 \mathrm{mi}[9.66 \mathrm{~km}]$ wide, which extends $15 \mathrm{mi}$ [24.14 km] westward from the central portion (see Figure 2). The city of Tulsa occupies $43.5 \mathrm{mi}^{2}$ [112.67 $\left.\mathrm{km}^{2}\right]$ and has a population of 265,000 people.
The elevation varies from $550 \mathrm{ft}$ [167.64 m] in the bed of the Arkansas River at the southeast corner of the county to slightly more than $950 \mathrm{ft}[289.56 \mathrm{~m}]$ at points northwest of Turley and $6 \mathrm{mi}[9.66 \mathrm{~km}]$ west of Sand Springs. The greatest local topographic relief is approximately $300 \mathrm{ft}$ [91.44 m]. The portion of the county east of a line drawn north-south through the city of Tulsa is generally of low relief. The underlying rock is mainly shale with intermittent slopes supported by beds of sandstone or limestone which dip westward at a rate of $40 \mathrm{ft}[12.19 \mathrm{~m}]$ to the mile. These slopes rise eastward until they are terminated by east-facing escarpments. The portion of the county west of the city of Tulsa is deeply dissected by streams with narrow valleys. An exception is the broad valley of the Arkansas River. The drainage of Tulsa County is by the Arkansas River and its tributaries, although Bird Creek and the Caney River are tributaries of the Verdigris River whose waters reach the Arkansas River east of the boundaries of Tulsa County. All of the large streams are muddy.

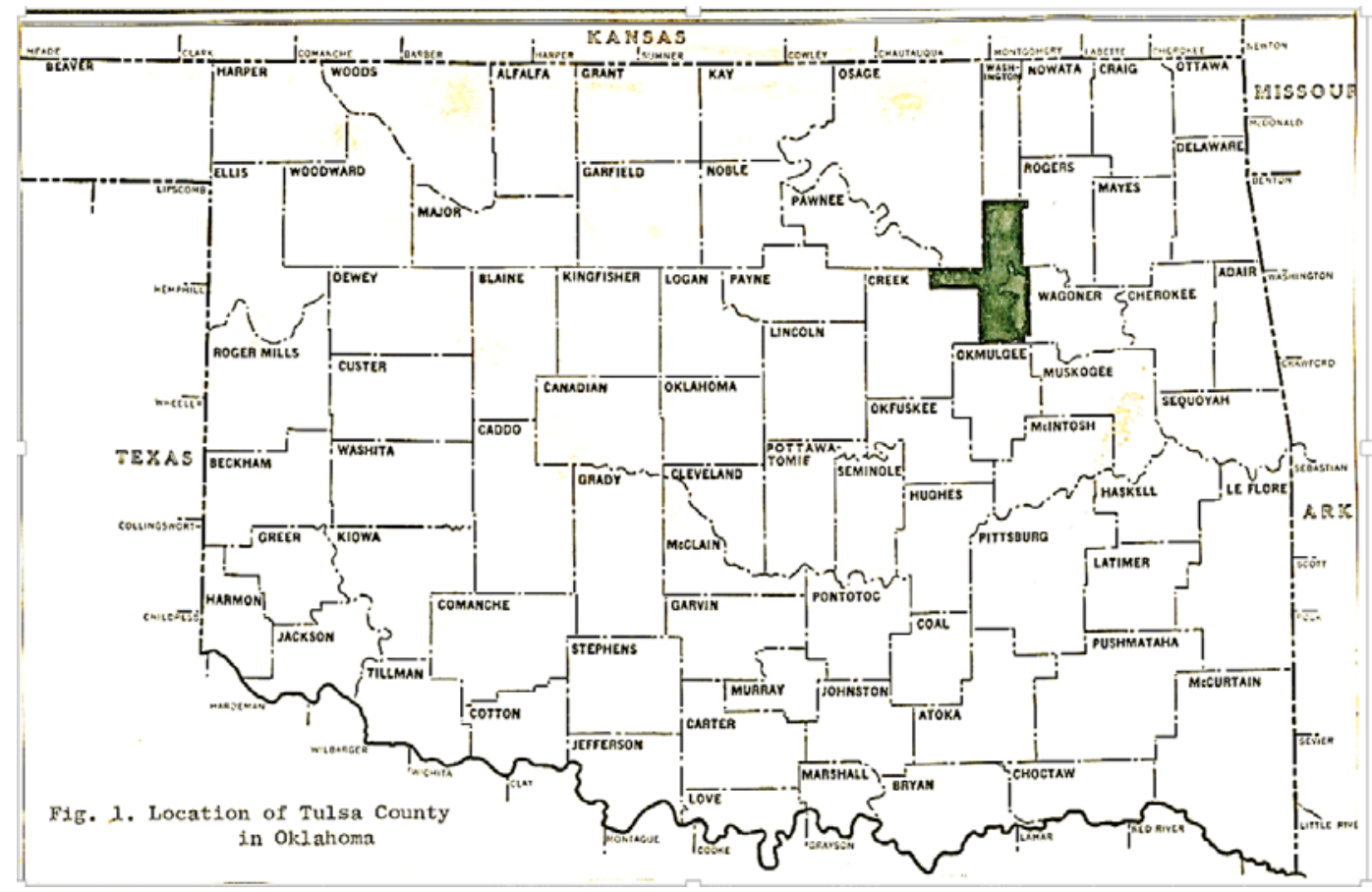

Figure 1 Location of Tulsa County in Oklahoma 
LEGEND

Collection Areas:

1. Caney River Area

2. Bird Creek Area

3. Arkansas River Flood Plain

4. Lost City

5. Concharty Mountain

6. Garnett Prairie

7. 31 st Street Prairie

8. City of Tulsa

$13 \mathrm{E} \quad 14 \mathrm{E}$

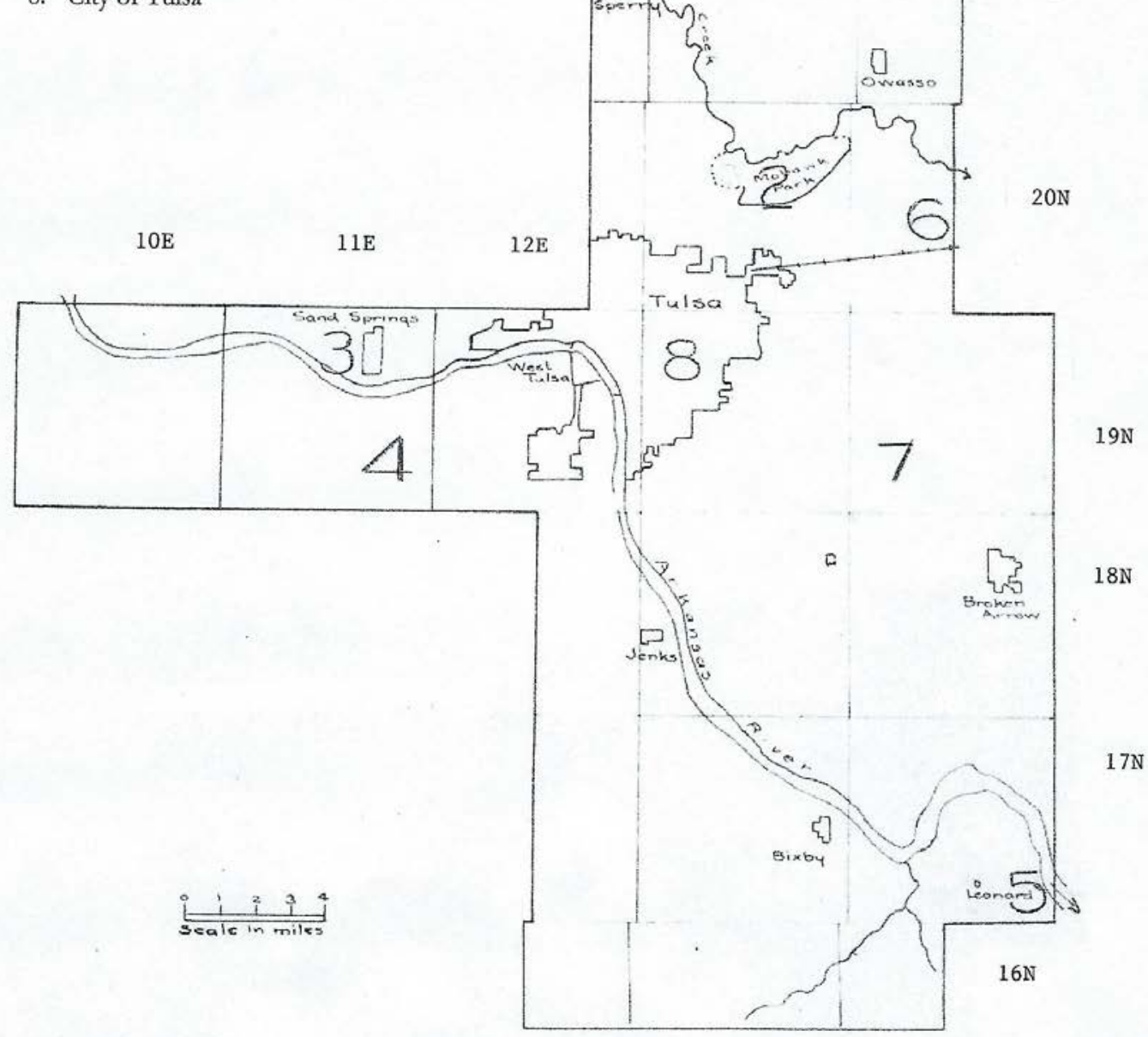

Figure 2 Map of collection areas, Tulsa County, Oklahoma [Map by J. M. Clark] 


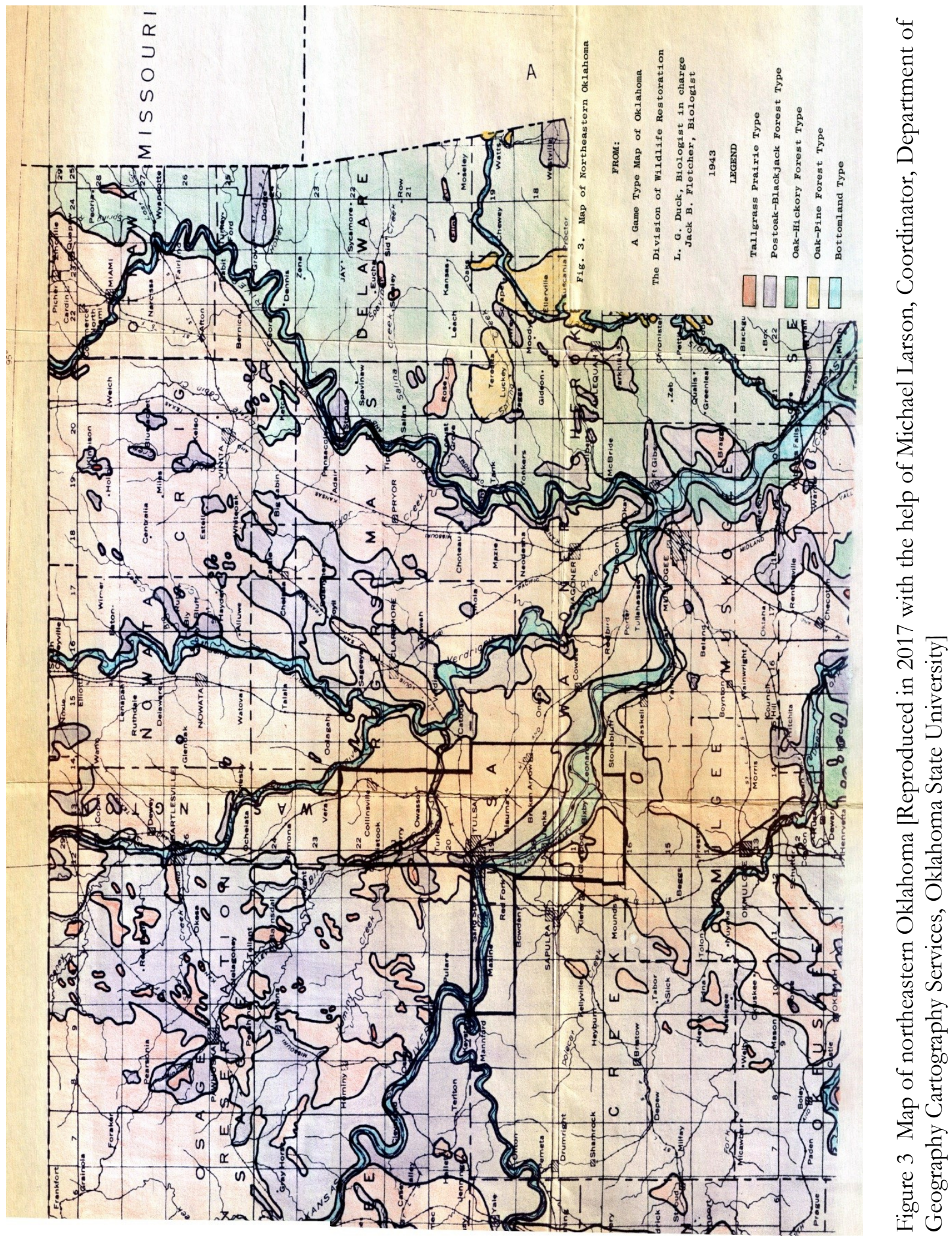




\section{Climate}

The climate of Tulsa County may be described as continental as there are no large water surfaces or mountains to affect climatic conditions. Data for 49 years, 1905-1955 inclusive, from the climatological records of the United States Department of Commerce Weather Bureau, located at the Tulsa Municipal Airport, indicate the average growing season is 219 days. The longest growing season on record, 258 days, occurred in 1907. The shortest season, 178 days, was in 1921. The average date of the last freezing temperature, $32^{\circ} \mathrm{F}$ $\left[0^{\circ} \mathrm{C}\right]$ or lower, in the spring is March 28 with the latest occurrence on record being April 20, 1953. The average date of the first freezing temperature in the fall is November 2, and the earliest occurrence on record is October 8, 1952. The temperature may frequently climb to $100^{\circ} \mathrm{F}\left[37.78^{\circ} \mathrm{C}\right]$ or more in July, August, and September, the highest on record being $112^{\circ} \mathrm{F}\left[44.44^{\circ} \mathrm{C}\right]$ in July 1954. The high temperatures are usually accompanied by low humidity and high evaporation. Zero $^{\circ} \mathrm{F}\left[-17.78^{\circ} \mathrm{C}\right]$ temperatures may be experienced for a few days in January, February, and occasionally in March. The lowest temperature recorded in the 49 year period was $-8^{\circ} \mathrm{F}\left[-22.22^{\circ} \mathrm{C}\right]$ in January 1947.

The mean annual rainfall is 37.16 in $[94.39 \mathrm{~cm}]$. The lowest annual precipitation recorded during the 1905-1955 period was 24.07 in $[61.14 \mathrm{~cm}]$ in 1910 , and the highest, 62.82 in [159.56 cm], was recorded in 1915. Rainfall is greatest in the spring months and least in the winter months. Records for the 49-year period show an average of 5.23 in [13.28 cm] of rainfall in May, 4.71 in $[11.96 \mathrm{~cm}]$ in June, and 4.18 in $[10.62 \mathrm{~cm}]$ in April. February averages 1.59 in $[4.04 \mathrm{~cm}]$; January, 1.74 in [4.42 cm]; and December, 1.83 in $[4.65 \mathrm{~cm}]$. Snowfall is slight and remains on the ground for a very short time.

Of particular interest are the collection years of 1956 and 1957. Unfortunately, the summary data from the weather bureau does not include these years. Some information, not in summary form, is available, however. In 1956, the growing season was 253 days in length with the last spring freeze occurring on March 20 and the first fall freeze on November 28. In 1957, the growing season was 223 days in length with the last spring freeze occurring on April 14 and the first fall freeze on November 23. The freeze of April 14 did much damage, particularly to the oaks, which formed few acorns. The precipitation of 23.24 in $[59.03 \mathrm{~cm}]$ in 1956 was the lowest ever recorded in Tulsa County. In sharp contrast, the precipitation in 1957 measured 46.50 in $[118.11 \mathrm{~cm}]$ with 9.80 in [24.89 cm] in May, 8.74 in $[22.2 \mathrm{~cm}]$ in April, and 7.25 in $[18.42 \mathrm{~cm}]$ in June.

Prevailing surface winds are southerly except during the months of December, January, and February. Sudden drops in temperature may accompany rapid change in wind direction in winter and spring.

\section{Ecology}

The major portion of Tulsa County is located in the Tall Grass Prairie region by Duck and Fletcher (1943; Figure 3). The long westward arm and the southeastern portion are in the Post Oak-Blackjack area. This type of vegetation also borders the alluvial flood plains of the streams. The ecological description given by Blair and Hubbell (1938) coincides with that given by Duck and Fletcher although they name the grassland the Cherokee Prairie Biotic District and the woodland the Osage Savannah Biotic District. Bruner (1931) sets the flood plain vegetation apart as a separate plant community. His description of the woody species of the flood plains of central Oklahoma is typical of that of Tulsa County as observed by the author.

Blair and Hubbell further describe the Cherokee Biotic District as an extension of the grasslands of eastern Kansas and western Missouri. The area is essentially 
composed of shale soils and limestone escarpments. The vegetation of the shale soils is described as composed of big bluestem (Andropogon gerardii), little bluestem (A. scoparius [Schizachyrium scoparium (Michx.) Nash]), Indian grass (Sorghastrum nutans), and switchgrass (Panicum virgatum).

Representative forbs associated with the grasses are false indigo (Baptisia leucophaea), blazing stars (Liatris punctata and L. aspera), starwort (Aster ericoides [Symphyotrichum ericoides (L.) G.L. Nesom]), sunflower (Helianthus mollis), and sage (Salvia azurea). Recent collections of blazing stars on the prairie in Tulsa County are Liatris aspera, L. angustifolia, L. mucronata [L. punctata var. mucronata (DC.) B.L. Turner], and L. pycnostachya. L. squarrosa was found in the wooded sandstone area and was not common. Blair and Hubbell described areas where the sod had been destroyed and is replaced by crabgrass (Digitaria sanguinalis, windmill grass (Chloris verticillata), and weeds such as broom-snakeroot (Gutierrezia dracunculoides [Amphiachyris dracunculoides (DC.) Nutt.]) and croton (Croton capitatus). On the limestone escarpments is found a mixture of tall grasses and shorter grasses such as side-oats grama (Boutelona curtipendula), buffalo grass (Buchloe dactyloides [Boutelona dactyloides (Nutt.) J.T. Columbus]), and silver beardgrass (Andropogon saccharoides [Botbriochloa laguroides (DC.) Herter]). Forbs are blue false indigo (Baptisia minor [Baptisia australis (L.) R. Br. var. minor (Lehm.) Fernald]), stone-crop (Sedum pulchellum), gaillardia (Gaillardia pulchella), prickly pears (Opuntia bumifusa and O. tortispina), and yucca (Yucca glauca). Widely scattered groves of small persimmon trees (Diospyros virginiana) dot the prairie, and persimmon and indigo bush (Amorpha fruticosa) may be found along the small prairie drains. The present author noted that areas with outcropping rocks frequently are covered with thickets of Chickasaw plum (Prunus angustifolia) and rough-leaved dogwood (Cornus drummondii). American elm (Ulmus americana), hawthorn
(Crataegus spp.) and wooly buckthorn (Bumelia lanuginosa [Sideroxylon lanuginosum Michx.]) are found along the larger drains. Bruner describes the eastern grassland as subclimax since it occurs in an area with potential forest climate. He further states that the forest has not developed because of the recurrence of prairie fires, but forest areas are increasing with the settlement of the area and the cessation of fires.

The Osage Savannah District is an area underlain by sandstone and is described by Blair and Hubbell as an open woodland with post oak (Quercus stellata), blackjack (Q. marilandica), and black hickory (Carya texana) as the dominant vegetation. Grasses in this association are of the prairie type, mainly bluestems. Shrubs are sumacs (Rhus glabra and $\mathrm{R}$ copallina) and coralberry (Symphoricarpos orbiculatus). On the northfacing slopes and the flood plains, a more mesic type of vegetation, similar to that of the Ozark area, will be found. Blair and Hubbell list red spotted oak (Quercus shumardii) as dominant in an association with redbud (Cercis canadensis), juneberry (Amelanchier arborea), and winged elm (Ulmus alata). Grasses conspicuous in this situation are spangle grass (Uniola latifolia [Chasmanthium latifolium Michx.]), wild rye (Elymus canadensis), and Japanese chess (Bromus japonica). The present author observed that chestnut oak (Quercus mueblenbergii), green ash (Fraxinus pennsylvanica var. integerrima [Fraxinus pennsylvanica Marsh. var. lanceolata (Borkh.) Sarg.]), white ash (F. americana), big-tree plum (Prunus mexicana), deciduous holly (Ilex decidua), and shrubs: black-haw (Viburnum rufidulum), fragrant sumac (Rhus aromatica), and poison ivy (R. toxicodendron [Toxicodendron radicans (L.) Kuntze]) occur with the red oaks, redbud, and juneberry on the north-facing slopes. In densely wooded areas are found wild-oat grass (Danthonia spicata), low twining legumes such as milkpea (Galactia volubilis), wild bean (Strophostyles 
leiosperma), and beggars ticks (Desmodium glutinosum).

The woody vegetation of the flood plains of Tulsa County consists of black willow (Salix nigra), cottonwood (Populus deltoides), sycamore (Platanus occidentalis), American elm (Ulmus americana), slippery elm (U. rubra), silver maple (Acer saccharinum), pecan (Carya illinoensis [Carya illinoinensis (Wangenh.) K. Koch]), red oaks (Quercus rubra and Q. shumardii), and the ashes. Pin oak (Q.palustris) is found at Mohawk Park on the Bird Creek flood plain. River birch (Betula nigra) and black walnut (Juglans nigra) were noted but are not prominent. Occasional black walnut trees were seen on all the major flood plains. River birches were observed on the Bird Creek flood plain and along a small tributary of the Arkansas River. Buttonbush (Cephalanthus occidentalis) and American elder (Sambucus canadensis [Sambucus nigra L. ssp. canadensis (L.) R. Bolli]) may be found along the streams. Common vines are trumpet vine (Campsis radicans), poison ivy (Rhus radicans [Toxicodendron radicans]), green briar (Smilax bona-nox), and members of the grape family: woodbine (Parthenocissus quinquefolia and Ampelopsis cordata) and grapes (Vitis aestivalis Michx. var. argentifolia and $V$. vulpina). Among the herbaceous plants are the rank growing composites which flower in late summer. Representative of these are ragweed (Ambrosia trifida), frost weed (Verbesina virginica), wingstem (Actinomeris alternifolia [Verbesina alternifolia (L.) Britton ex Kearney]), bearsfoot (Polymnia uvedalia [Smallanthus uvedalia (L.) Mack. ex Small]), green-stemmed Joe-Pye-weed (Eupatorium purpureum [Eutrochium purpureum (L.) E.E. Lamont]), white snakeroot (E. rugosum [Ageratina altissima (L.) King \& H. Rob. var. altissima]), cup-plant (Silphium perfoliatum), goldenrods (Solidago spp.), and asters (Aster [Symphyotrichum] spp.).

Man and his domestic animals are of ecological significance in Tulsa County. With the fast growing population of the city of Tulsa and the consequent construction of homes, industries, and highways, many of the indigenous plants are being destroyed. As the periphery of the city increases, more suburban homes and shopping centers are being built. Prairie areas are replaced by homes with mowed lawns; small streams are routed through conduits and covered, destroying the habitat of plants with high moisture requirement. Construction of water reservoirs and dams, currently the Keystone Dam on the Arkansas River, destroys much of the lowland vegetation. Limestone quarries to satisfy the increased need for concrete are destroying the Garnett Prairie, northeast of Tulsa. In the remaining farming areas, over-grazing and trampling by domestic animals, particularly in drouth years, has effected the replacement of many native grasses and legumes by undesirable weeds. A rapid increase in the urban aspect of Tulsa County is evident.

\section{COLLECTION AREAS}

\section{Caney River Area}

Definite collection areas which might produce a variation in the flora due to ecological differences were established and visited regularly. The Caney River area, located in the northeastern corner of the county and two and one-half miles [4.02 km] northeast of Collinsville, T $22 \mathrm{~N}$, R 14 E, [Indian Meridian] (see Figure 2; Figure 4), consists of alluvium deposited on sandstone and shale. Of special interest are the wooded area surrounding an ox bow lake and the vegetation on the east-facing slope of the sandstone escarpment west of the Caney River. Difficulty was encountered in collecting vernal specimens due to excessive flooding of the Caney River. Specimens located here and not found by the author elsewhere in the county are Dicentra cucullaria, Paronychia canadensis, Staphylea trifolia, Forestiera acuminata, Myosurus minimus, Heliotropium indicum, and Abutilon theophrasti. 


\section{Bird Creek Area}

The Bird Creek area, located at T $20 \mathrm{~N}$, R 13 E, [Indian Meridian] (see Figure 2), consists of alluvium and forms the north boundary of Mohawk Park. This area is of particular interest because of the undisturbed areas designated as wildflower and bird sanctuaries. Species collected here and not found elsewhere in the county are Quercus palustris, Lindera benzoin, Dentaria laciniata [Cardamine concatenata (Michx.) Sw.], Impatiens capensis, Phryma leptostachya, Sicyos angulatus, and Lysimachia ciliata. In general, there is much similarity between the plants of the Bird Creek area and the Caney River area. The only specimens of Asimina triloba and Campanula americana var. illinoensis were found in these two areas.

\section{Arkansas River Flood Plain}

The Arkansas River flood plain, characterized by alluvial sands shifted by a variable volume of water and wind, enters the county at Keystone, T 19 N, R 10 E, [Indian Meridian], extends east and southeastwardly and leaves the county at T 17 N, R 14 E (see Figure 2; Figure 5). Among the species collected on the sandflats of the river bed and bank in August during the drouth of 1956 are Dalea lanata, Cycloloma atriplicifolium, Chenopodium murale, and Urtica dioica. Chenopodium murale is listed in Waterfall (1952a) with the notation "none seen." Urtica dioica, a perennial urtica, had not been previously collected in Oklahoma. The only other known Oklahoma collection of this species was made by C. S. Wallis in 1957 in the Ozark area.

\section{Lost City Area}

Escarpments, created by the Arkansas River flowing over westward dipping beds of unequal hardness, are made up of the more resistant limestones and sandstones. Of these is the area known as Lost City, which is south of the Arkansas River, slightly east of Sand Springs in T 19 N,
R 11 E, [Indian Meridian], on a road called Scenic Drive, an extension of West 21 Street (see Figure 2; Figure 6). Massive bluffs of Hogshooter Limestone face north and provided a favorite collecting area. Cotinus obovatus, Celastrus scandens, Aquilegia canadensis var. latiscula, Ribes odoratum [Ribes aureum Pursh var. villosum DC.], and Zigadenus nuttallii [Toxicoscordion nuttallii (A. Gray) Rydb.] are among the plants located here and not collected elsewhere in the county.

\section{Concharty Mountain Area}

In the southeast corner of the county, south of the Arkansas River flood plain and southeast of Leonard, T 17 N, R 14 E, [Indian Meridian], is located the northfacing slope of Concharty Mountain [(Figure 7)]. The mountain is underlain by sandstone and has a relief of about 300 feet [91.44 m]. Plants collected here and not found elsewhere in the county are Saxifraga texana [Micranthes texana (Buckley) Small], Lonicera flava, Ascyrum bypericoides var. multicaule [Hypericum byperericoides (L.) Crantz ssp. multicaule (Michx. ex Willd.) N. Robson], Gerardia grandiflora var. cinerea [Aureolaria grandiflora (Benth.) Pennell], Pycnanthemum tenuifolium, and Centunculus minimus [Anagallis minima (L.) E.H.L. Krause].

\section{Prairie Areas}

Prairie areas [(Figures 8, 9)] which were visited regularly are: Garnett Prairie, located two miles [3.22 km] north and two miles east of the traffic circle on State Highway 33 in T 20 N, R 14 E [Indian Meridian] (see Figure 2); a section of the Saint Louis-San Francisco Railroad right-of-way located one and one-half miles [2.41 km] north and two miles east of the traffic circle in T $20 \mathrm{~N}$, R 14 E, [Indian Meridian] (see Figure 2); and an area known as the $31^{\text {st }}$ Street Prairie, six miles [9.66 km] east of Harvard Avenue on $31^{\text {st }}$ Street, T 19 N, R 14 E [Indian Meridian] (see Figure 2). All the above are underlain by the Oolagah Limestone. These afford a wealth of specimens typical of the 
Tall Grass Prairie region. The area known as Garnett Prairie is currently about to be destroyed by the encroachment of a commercial plant for crushing limestone. The railroad right-of-way was not burned, mowed, or trampled by domestic animals during the collection period. The $31^{\text {st }}$ Street Prairie was annually mowed on about July 20. Prominent among the plant families represented are the Compositae [Asteraceae], Leguminosae [Fabaceae], Cruciferae [Brassicaceae], Euphorbiaceae, and Labiatae [Lamiaceae]. Plants collected in the Garnett Prairie area, including the railroad right-of-way, and not found elsewhere are Eriogonum longifolium, Cucurbita foetidissima, Isanthus brachiatus [Trichostema brachiatum L.], Hybanthus linearis [Hybanthus verticillatus (Ortega) Baill.], and Nama bispidum.

\section{Other Collection Areas}

No attempt was made to visit other collection areas regularly, but roadside ditches and bordering fields traversed coincidental to traveling to collection sites were kept under observation. Occasional trips were taken to the areas west of Sand Springs, north of the Arkansas River to the Osage County line; southwest of Sand Springs, south of the Arkansas River to an area near the Creek County line; and south of Bixby to the Okmulgee County line. Some weeds from Tulsa city streets and lawns were collected. Of these is a small plant, Veronica hederaefolia [Veronica hederifolia L.], which had not previously been collected in Oklahoma. Gray's Manual (Fernald 1950) lists the range of this plant as New York and Ohio to North Carolina. The plant was found under a mulberry tree which was a favorite feeding place for migratory birds.

\section{SUMMARY OF SPECIES}

The list of plants of Tulsa County consists of 99 families made up of 335 genera and 585 species. The largest families in order of number of species are: Compositae [Asteraceae], 53 genera and 110 species; Leguminosae [Fabaceae], 33 genera and 50 species; Euphorbiaceae, 7 genera and 22 species; Cruciferae [Brassicaceae], 16 genera and 21 species; Rosaceae, 9 genera and 19 species; Scrophulariaceae [Linderniaceae, Orobanchaceae, Phrymaceae, Plantaginaceae, Scrophulariaceae], 12 genera and 18 species; Labiatae [Lamiaceae], 13 genera and 16 species; Polygonaceae, 4 genera and 16 species; and Onagraceae, 4 genera and 15 species. Twenty-eight families are represented by one species each. 


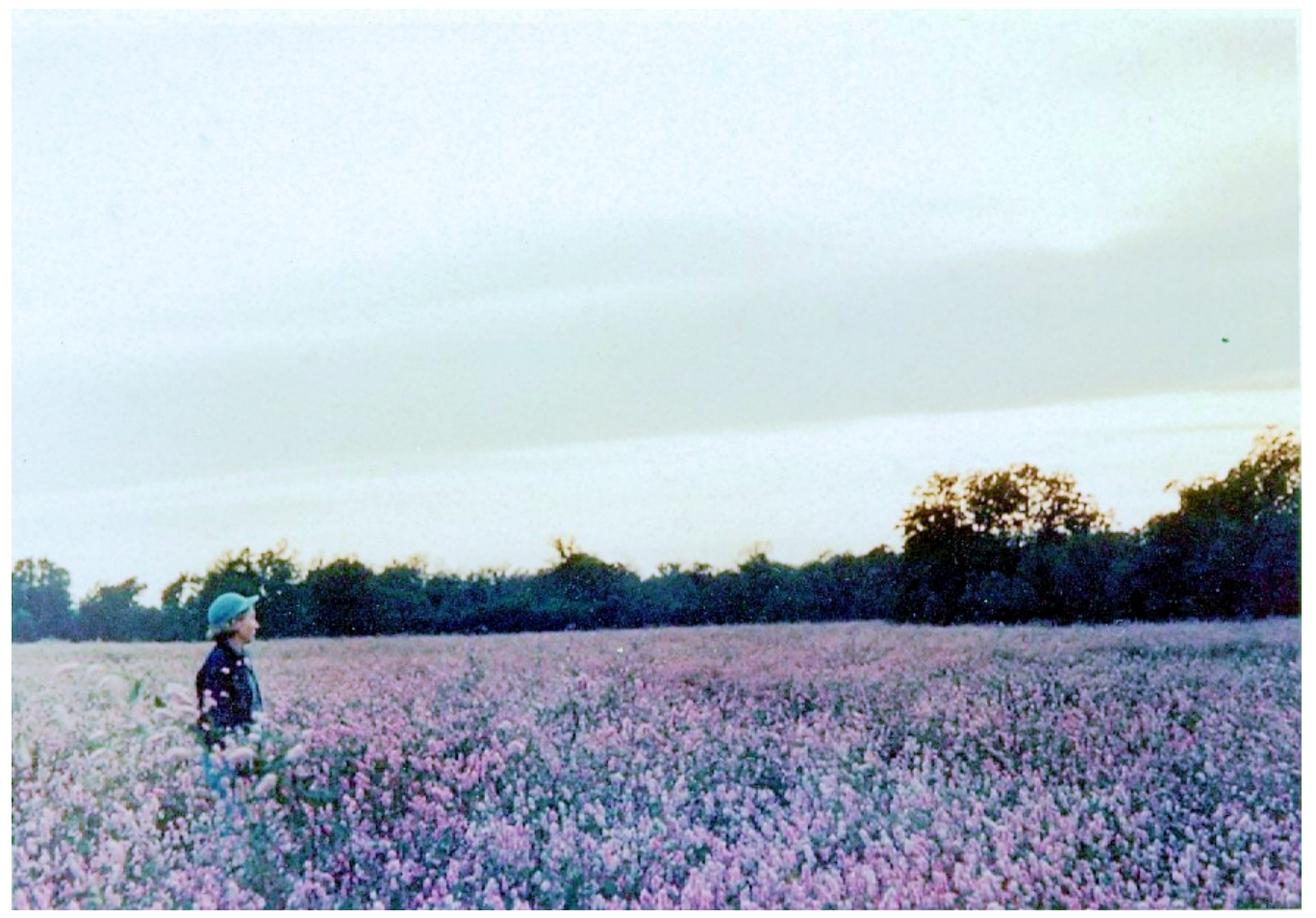

Figure 4 Caney River Area. The flood plain forest is in the background. Polygonum longistylum [Persicaria bicornis (Raf.) Nieuwl.] covers a recently flooded field in the foreground.

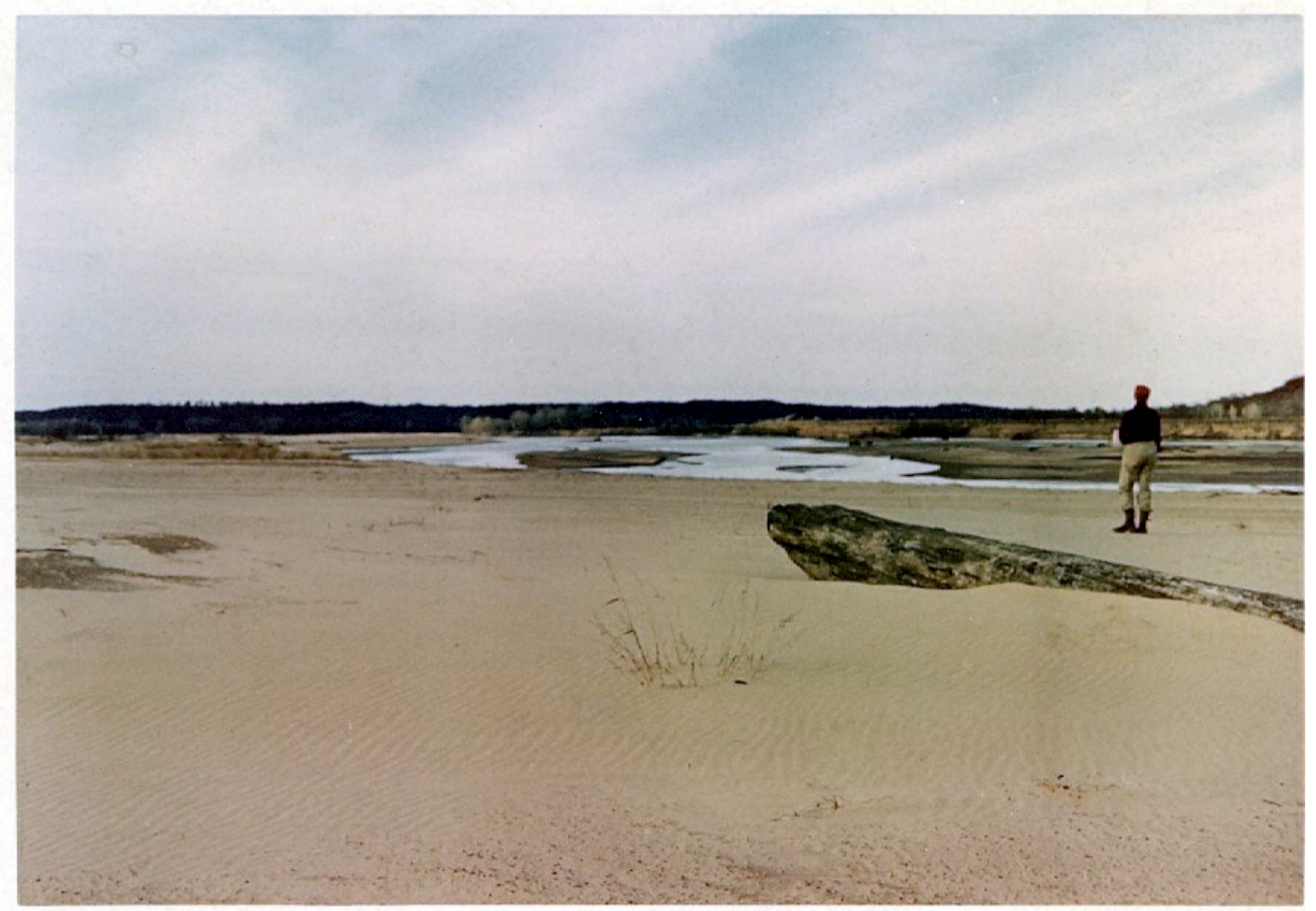

Figure 5 Sand Flats of the Arkansas River. Photograph was taken in October, 1957. The river recedes after spring flooding, and large quantities of sand are deposited in the channel. 


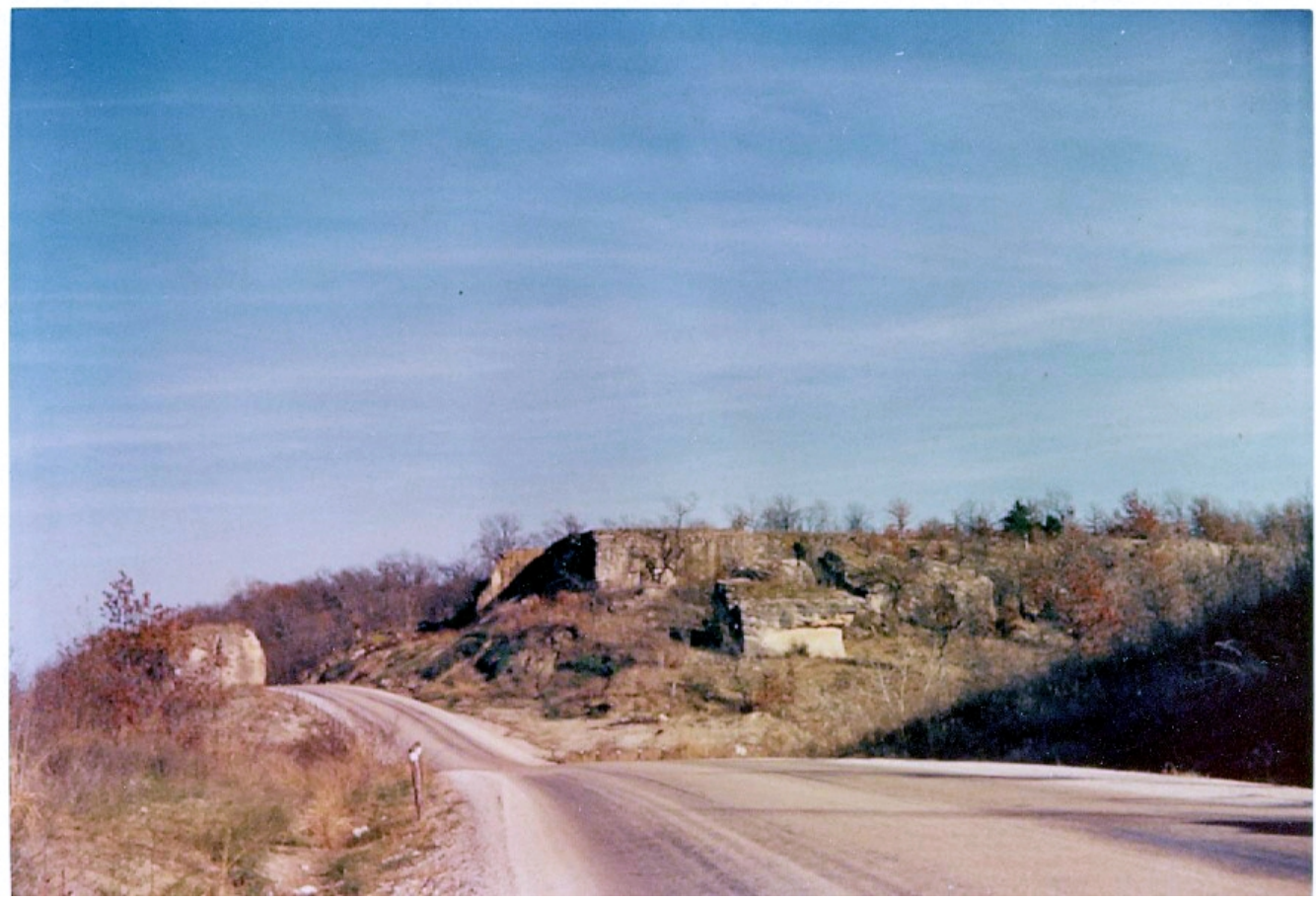

Figure 6 Lost City Area. Massive blocks of Hogshooter Limestone rise above the Arkansas River flood plain and provide a north-facing habitat.

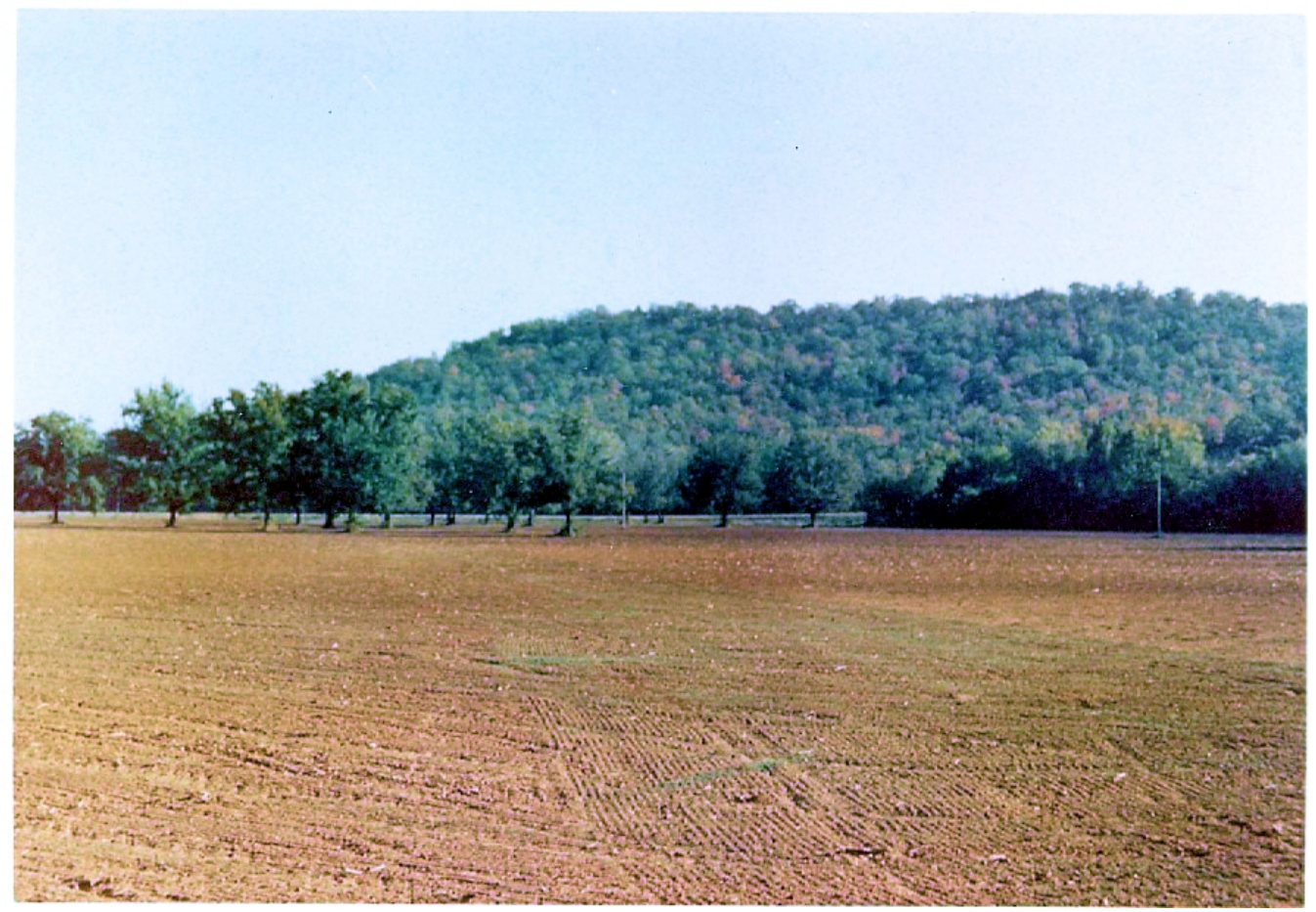

Figure 7 Concharty Mountain. The north-facing slope of the mountain rises 300 feet $[91.44 \mathrm{~m}]$ above the Arkansas River flood plain. 


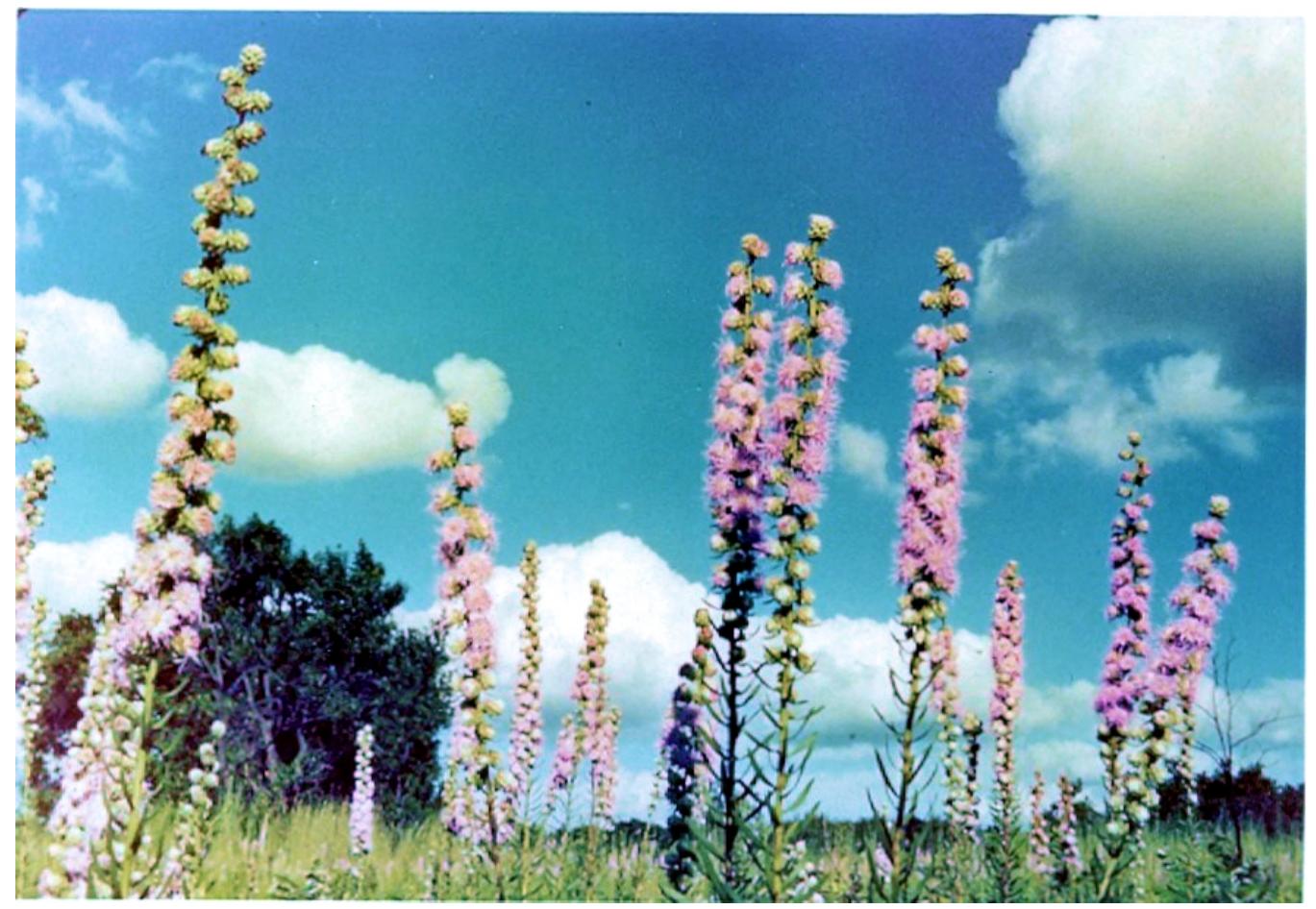

Figure 8 Forbs of the Tall Grass Prairie Area. In the foreground is the composite, Liatris aspera, which measures $4 \mathrm{ft}[1.22 \mathrm{~m}]$ in height and is common on the Tall Grass Prairie. A flood plain forest is visible in the background.

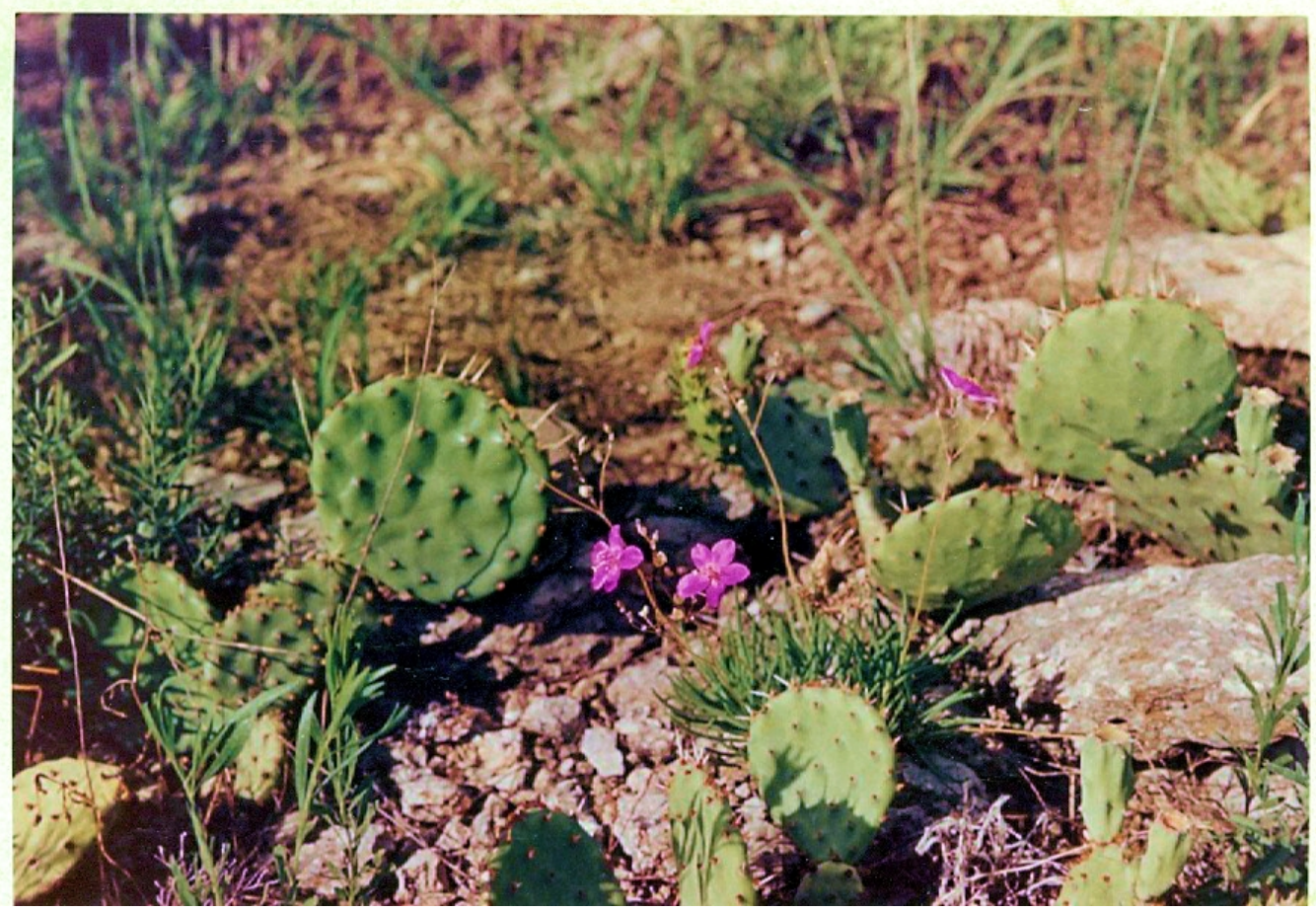

Figure 9 Garnett Prairie Area. The rock outcrop is the Oolagah Limestone.

Cactus (Opuntia macrorbiza) and flameflower (Talinum calycinum [Phemeranthus calycinus (Engelm.) Kiger]) are rooted between the rocks. 


\section{ACKNOWLEDGMENTS}

The author wishes to express her appreciation to Dr. Ralph W. Kelting for directing this study, for assistance in collecting plants, and for the many hours spent in rechecking specimens. She also wishes to thank Dr. Harriet G. Barclay for stimulating an interest in field botany, Dr. A. P. Blair for assistance in finding unusual specimens, and Dr. George J. Goodman and Dr. U. T. Waterfall for offering the facilities of the herbaria of the University of Oklahoma and Oklahoma State University. She also wishes to thank her husband, J. M. Clark, for providing the maps which appear in this thesis, for interpreting the geology of Tulsa County, and for his patience during the past three years.

\section{LITERATURE CITED}

Blair, W.F. and T.H. Hubbell. 1938. The biotic districts of Oklahoma. American Midland Naturalist 20:425-455.

Bruner, W.E. 1931. The vegetation of Oklahoma. Ecological Monographs 1:99_ 188.

Duck, L.G. and J.B. Fletcher. 1943. A game type map of Oklahoma. Oklahoma City $(\mathrm{OK})$ : Division of Wildlife Restoration, Oklahoma Game and Fish Department.

Duck, L.G. and J.B. Fletcher. 1945. A survey of the game and furbearing animals of Oklahoma. Oklahoma Game and Fish Commission Bulletin 3:19-29.

Fassett, N.C. 1940. A Manual of Aquatic Plants. New York: McGraw-Hill Book Co.

Fernald, M.L. 1934. Draba in temperate northeastern America. Rhodora 36:368369.

Fernald, M.L. 1950. Gray's Manual of Botany, $8^{\text {th }}$ ed. Dallas: American Book Co.

Gleason, H.A. 1952. New Britton and Brown Illustrated Flora of the Northeastern United
States and Canada. New York: New York Botanical Garden. Vols. 1-3.

Goodman, G.J. (no date). Keys to the Spring Flora of Central Oklahoma. Norman [(OK)]: Department of Plant Sciences, The University of Oklahoma.

Harrar, E.S. and J.G. Harrar. 1946. Guide to Southern Trees. New York: Whittlesey House, McGraw-Hill Book Co.

Kelting, R.W. and W.T. Penfound. 1953. Literature on the vegetation of Oklahoma. Proceedings of the Oklahoma Academy of Science 34:126-135.

Little, E.L. 1938. Flora of Muskogee County, Oklahoma. American Midland Naturalist 19:369-389.

Little, E.L. 1938. The vegetation of Muskogee County, Oklahoma. American Midland Naturalist 19:369-389.

McCoy, D. 1952. The genus Lythrum in Oklahoma. Proceedings of the Oklaboma Academy of Science 33:156-158.

McCoy, D. 1958. Vascular plants of Pontotoc County, Oklahoma. American Midland Naturalist 59:371-396.

Millspaugh, C.F. and E.E. Sherff. 1919. Revision of North American Species of Xanthium. Chicago: Field Museum of Natural History.

Munz, P.A. 1938. Studies in Onagraceae XI. A revision of the genus Gaura. Bulletin of the Torrey Botanical Club 65:105-122; 211-228.

Oakes, M.C. 1952. Geology and mineral resources of Tulsa County, Oklahoma. Oklahoma Geological Survey Bulletin 39:7-16.

Rydberg, P.A. 1932. Flora of the Prairies and Plains of Central North America. New York: New York Botanical Garden.

Shinners, L.H. 1958. Spring Flora of the Dallas-Fort Worth Area Texas. Dallas: Southern Methodist University.

Small, J.K. 1933. Manual of the Southeastern Flora. New York: self-published.

Stemen, R.R. and W.S. Myers. 1937. Oklahoma Flora. Oklahoma City [(OK)]: Harlow Publishing Co. 
Steyermark, J.A. 1940. Spring Flora of Missouri. St. Louis: Missouri Botanical Garden.

Trelease, W. 1931. Winter Botany. Urbana (IL): self-published.

United States Department of Agriculture. 1949. Trees. Yearbook of Agriculture.

Waterfall, U.T. 1952. Further studies of Oklahoma flora. Rhodora 54:125-131.
Waterfall, U.T. 1952a. A Catalogue to the Flora of Oklahoma. Stillwater [(OK)]: The Research Foundation, Oklahoma Agricultural and Mechanical College.

Waterfall, U.T. 1953-1955-1957. Keys to the Flora of Oklahoma. Parts 1-3. Unnumbered mimeo. Stillwater [(OK)]: Oklahoma Agricultural and Mechanical College. 


\title{
APPENDIX \\ List of Species Found in Tulsa County
}

Editor's Note: Where nomenclature has been updated using ITIS-Integrated Taxonomic Information Service (http://www.itis.gov), the revised name is in brackets [ ]. Unless otherwise indicated, the numbers in parentheses following the species are the collection numbers of the author.

\section{MONOCOTYLEDONEAE}

\section{Typhaceae}

Typha latifolia L. (414)

\section{Zosteraceae [Potamogetonaceae]}

Potamogeton diversifolius Raf. (Kelting 1038A)

\author{
Alismataceae \\ Echinodorus cordifolius (L.) Griseb. (626) \\ Echinodorus rostratus (Nutt.) Engelm. [Echinodorus berteroi (Spreng.) Fassett] (482) \\ Sagittaria graminea Michx. (458)
}

Sagittaria platyphylla (Engelm.) J.G. Sm. (619)

\section{Araceae}

Arisaema atrorubens (Ait.) Blume [Arisaema triphyllum (L.) Schott.] (236)

Arisaema dracontium (L.) Schott. (214)

\section{Lemnaceae [Araceae]}

Lemna minor L. (666)

Spirodela polyrhiza (L.) Schleid (667)

\section{Commelinaceae}

Commelina communis L. var. ludens (Miguel) Clarke [Commelina communis L.] (23)

Commelina erecta L. var. angustifolia (Michx.) Fern. [Commelina erecta L.] (375)

Tradescantia occidentalis (Britt.) Symth (241)

Tradescantia ohiensis Raf. (321)

\section{Pontederiaceae}

Heteranthera limosa (Sw.) Willd.

\section{Liliaceae}

Allium canadense L. var. hyacinthoides (Bush) Ownbey [Amaryllidaceae] (908)

Allium drummondii Regel [Amaryllidaceae] (Barclay unnumbered)

Camassia scilloides (Raf.) Cory [Asparagaceae] (219)

Erythronium albidum Nutt. var. mesochoreum (Knerr) Rickett [Erythronium mesochoreum Knerr] (129)

Nothoscordum bivalve (L.) Britton [Amaryllidaceae] (166)

Polygonatum canaliculatum (Muhl.) Pursh [Polygonatum biflorum (Walter) Elliott] [Asparagaceae] (315)

Smilax bona-nox L. [Smilacaceae] (662) 
Smilax herbacea L. [Smilacaceae] (396A, 562, 873)

Yucca glauca Nutt. var. glauca [Yucca glauca Nutt.] [Asparagaceae] (280)

Zigadenus nuttallii Gray [Toxicoscordion nuttallii (A. Gray) Rydb.] [Melanthiaceae] (240)

\section{Amaryllidaceae}

Cooperia drummondii Herb. [Zephyranthes chlorosolen (Herb.) D. Dietr.] (568, 641, 981, 983)

Hypoxis hirsuta (L.) Coville $(216,228)$

\section{Iridaceae}

Nemastylis geminiflora Nutt. (243)

Sisyrinchium angustifolium Mill. (245)

Sisyrinchium campestre Bickn. (Kelting 1007)

\section{Orchidaceae}

Spiranthes cernua (L.) Richards $(355,671,720)$

\section{DICOTYLEDONEAE}

\section{Salicaceae}

Populus deltoides Marsh. [Populus deltoides W. Bartram ex. Marshall] $(775,885)$

Salix interior Rowlee $(110,883)$

Salix nigra Marsh. [Salix nigra Marshall] $(792,885)$

\section{Juglandaceae}

Carya cordiformis (Wang.) K. Koch (689)

Carya illinoensis (Wang.) K. Koch [Carya illinoinensis (Wang.) K. Koch] (515)

Carya texana Buckl. var. texana [Carya texana Buckl.] (866)

Juglans nigra L. (727)

\section{Corylaceae [Betulaceae]}

Betula nigra L. (729)

\section{Fagaceae}

Quercus macrocarpa Michx. (733)

Quercus marilandica Muench. (716)

Quercus muehlenbergii Engelm. $(875,880)$

Quercus palustris Muench. (664)

Quercus prinoides Willd. (Kelting 1008A)

Quercus rubra L. $(665,732,798)$

Quercus shumardii Buckl. var. shumardii [Quercus shumardii Buckl.] $(724,725)$

Quercus shumardii Buckl. var. schneckii (Britton) Sarg. [Quercus shumardii Buckl.] (723)

Quercus stellata Wang. var. stellata [Quercus stellata Wang.] (874)

Quercus velutina Lam. (728)

\section{Ulmaceae}

Celtis laevigata Willd. var. laevigata [Celtis laevigata Willd.] [Cannabaceae] $(100,869,871)$

Ulmus alata Michx. (135) 
Ulmus americana L. (130)

Ulmus rubra Muhl. (138)

\section{Moraceae}

Morus rubra L. (789)

\section{Urticaceae}

Laportea canadensis (L.) Wedd. (551)

Parietaria pennsylvanica Muhl. [Parietaria pensylvanica Muhl. ex Willd.] (311)

Urtica chamaedryoides Pursh (397)

Urtica dioica L. (95)

\section{Loranthaceae [Santalaceae]}

Phoradendron flavescens (Pursh) Nutt. [Phoradendron serotinum ssp. serotinum (Raf.) M.C. Johnst.] (757)

\section{Aristolochiaceae}

Aristolochia tomentosa Sims (249)

\section{Polygonaceae}

Eriogonum annuum Nutt. (498)

Eriogonum longifolium Nutt. (572)

Polygonum aviculare L. var. aviculare [Polygonum aviculare L.] $(113,373,508 \mathrm{~A})$

Polygonum convolvulus L. [Fallopia convolvulus (L.) Á. Löve] (372)

Polygonum cristatum Engelm. \& Gray [Fallopia scandens (L.) Holub] $(613,661)$

Polygonum hydropiperoides Michx. var. hydropiperoides [Persicaria hydropiperoides (Michx.) Small] $(486,602,734)$

Polygonum hydropiperoides Michx. var. bushianum Stanford [Persicaria hydropiperoides (Michx.)

Small] (621)

Polygonum lapathifolium L. [Persicaria lapathifolia (L.) Gray] $(628,636,685)$

Polygonum longistylum Small [Persicaria bicornis (Raf.) Nieuwl.] $(527,714)$

Polygonum pennsylvanicum L. var. pennsylvanicum [Persicaria pensylvanica (L.) M. Gómez] (611)

Polygonum punctatum var. punctatum [Persicaria punctata (Elliott) Small] (462)

Polygonum tenue Michx. (674)

Rumex altissimus Wood (268)

Rumex crispus L. (317)

Rumex hastatulus Baldw. (863)

Tovara virginiana (L.) Raf. [Persicaria virginiana (L.) Gaertn.] $(554,633)$

\section{Chenopodiaceae [Amaranthaceae]}

Chenopodium album L. (756)

Chenopodium ambrosioides L. var. ambrosioides [Dysphania ambrosioides (L.) Mosyakin \& Clemants] (687)

Chenopodium hybridum L. var. gigantospermum (Aellen) Rouleau [Chenopodium simplex (Torr.) Raf.] (519)

Chenopodium leptophyllum Nutt. [Chenopodium leptophyllum (Moq.) Nutt. ex S. Watson] (27)

Chenopodium murale L. (107)

Cycloloma atriplicifolium (Spreng) Coult. (96)

Salsola kali L. var. tenuifolia Tausch [Salsola tragus L.] (15) 


\section{Amaranthaceae}

Acnida tamarascina (Nutt.) Wood [Amaranthus tuberculatus (Moq.) J.D. Sauer] (625)

Amaranthus hybridus L. (700)

Amaranthus palmeri S. Wats. (750)

Froelichia floridana (Nutt.) Moq. var. campestris (Small) Fern. [Froelichia floridana (Nutt.) Moq.] $(125,593)$

Froelichia gracilis (Hook.) Moq. (52)

Iresene rhizomatosa Standl. [Iresine rhizomatosa Standl.] (637)

\section{Nyctaginaceae}

Mirabilis albida (Walt.) Heimerl. $(92,410)$

Mirabilis nyctaginea (Michx.) MacM. $(289,578,857)$

\section{Phytolacaceae}

Phytolacca americana L. (737)

\section{Aizoaceae [Molluginaceae]}

Mollugo verticillata L. (369)

\section{Portulacaceae}

Claytonia virginica L. [Montiaceae] (154)

Portulaca mundula I.M. Jtn. [Portulaca pilosa L.] $(102,359)$

Portulaca oleracea L. (85)

Talinum calycinum Engelm. [Phemeranthus calycinus (Engelm.) Kiger] [Montiaceae] (345)

Talinum parviflorum Nutt. [Phemeranthus parviflorus (Nutt.) Kiger] [Montiaceae] (Barclay unnumbered)

\section{Caryophyllaceae}

Arenaria patula Michx. [Minuartia patula (Michx.) Mattf.] (189)

Arenaria stricta Michx. var. texana Robinson [Minuartia michauxii (Fenzl) Farw.] (293)

Cerastium brachypodum (Engelm.) Robinson [Cerastium brachypodum (Engelm. ex A. Gray)

B.L. Rob.] 168, 173, 186, 190)

Cerastium viscosum L. [Cerastium glomeratum Thuill.] (172)

Paronychia canadensis (L.) Woods (384)

Paronychia fastigata (Raf.) Fern. (503)

Silene antirrhina L. (209)

Silene stellata (L.). Ait. f. var. scabrella (Niewl.) Palm. \& Steyerm. [Silene stellata (L.) Ait. f.] $(50,53)$

Stellaria media (L.) Cyrill (991)

Stellaria nuttallii T. \& G. [Minuartia drummondii (Shinners) McNeill] $(247,258)$

\section{Nymphaceae [Nymphaeaceae]}

Nelumbo lutea (Willd.) Pers. [Nelumbonaceae] (607)

Nymphea tuberosa Paine [Nymphaea odorata Aiton ssp. tuberosa (Paine) Wiersema \& Hellq.] (496)

\section{Ranunculaceae}

Anemone caroliniana Walt. $(163,164)$

Aquilegia canadensis L. var. latiscula (Greene) Munz [Aquilegia canadensis L.] (237)

Clematis pitcheri T. \& G. [Clematis pitcheri Torr. \& A. Gray] $(68,387)$ 
Delphinium virescens Nutt. var. virescens [Delphinium carolinianum Walter ssp. virescens (Nutt.)

R.E. Brooks] (11)

Isopyrum biternatum (Raf.) T \& G. [Enemion biternatum Raf.] (Kelting 1004)

Myosurus minimus L. (204)

Ranunculus abortivus L. var. abortivus [Ranunculus abortivus L.] (183)

Ranunculus fascicularis Muhl. var. fascicularis $(155,199)$

Thalictrum dasycarpum Fisch.\& Lall. var. hypoglaucum (Rydb.) Boivin [Thalictrum dasycarpum Fisch. \& Lall.] (54)

\section{Berberidaceae}

Podophyllum peltatum L. (787)

\section{Menispermaceae}

Cocculus carolinus (L.) DC. (437)

Menispermum canadense L. $(648,657)$

Annonaceae

Asimina triloba Dunal [Asimina triloba (L.) Dunal] $(224,390,653,788)$

\section{Lauraceae}

Lindera benzoin (L.) Blume var. pubescens (Palmer and Steyerm.) Rehd. [Lindera benzoin (L.) Blume] (559)

Lindera benzoin (L.) Blume var. undetermined [Lindera benzoin (L.) Blume] (769)

\section{Papaveraceae}

Argemone intermedia Sweet [Argemone polyanthemos (Fedde) G.B. Ownbey] (248)

Corydalis crystallina Engelm. (207)

Corydalis micrantha (Engelm.) Gray [Corydalis micrantha (Engelm. ex A. Gray) A. Gray] (181)

Dicentra cucullaria (L.) Bernh. $(208,778)$

\section{Cruciferae [Brassicaceae]}

Brassica nigra (L.) Koch (227)

Camelina microcarpa Andrz. [Camelina microcarpa DC.] $(188,215)$

Capsella bursa-pastoris (L.) Medic. (201)

Cardamine parviflora L. var. arenicola (Britt.) O.E. Schulz [Cardamine parviflora L.] (160)

Cardamine pennsylvanica Muhl. [Cardamine pensylvanica Muhl. ex Willd.] (784)

Conringia orientalis (L.) Dumort. (167)

Dentaria laciniata Muhl. [Cardamine concatenata (Michx.) Sw.] (772)

Descurainia pinnata (Walt.) Britt. [Descurainia pinnata (Walter) Britton] (146)

Draba brachycarpa Nutt. [Draba brachycarpa Nutt. ex Torr \& A. Gray] (174)

Draba cuneifolia Nutt. var. cuneifolia [Draba cuneifolia Nutt. var. cuneifolia Nutt. ex Torr. \& A. Gray] (147)

Draba reptans (Lam.) Fern. var. reptans [Draba reptans (Lam.) Fernald] $(127,156)$

Erysimum asperum DC. $(212,231,570)$

Erysimum repandum L. (170)

lodanthus pinnatifidus (Michx.) Steud. (649)

Lepidium densiflorum Schrad. (257)

Lepidium virginicum L. (865)

Lesquerella gracilis (Hook.) Wats. var. repanda (Nutt.) Payson [Physaria gracilis (Hook.) O'Kane \&

Al-Shehbaz ssp. nuttallii (Torr. \& A. Gray) O'Kane \& Al-Shehbaz] $(165,232)$ 
Rorippa sessiliflora (Nutt.) Hitchc. (627)

Selenia aurea Nutt. (148)

Sibara virginica (L.) Rollins [Planodes virginica (L.) Greene] $(131,161)$

Thlaspi arvense L. (779)

\section{Crassulaceae}

Sedum nuttallianum Raf. [Sedum nuttallii Torr. \& E. James ex Eaton] (906)

Sedum pulchellum Michx. (260)

\section{Saxifragaceae}

Penthorum sedoides L. [Penthoraceae] $(574,616)$

Ribes odoratum Wendland f. [Ribes aureum Pursh var. villosum DC.] [Grossulariaceae] (158)

Saxifraga texana Buckl. [Micranthes texana (Buckley) Small] (194)

\section{Platanaceae}

Platanus occidentalis L. (758)

\section{Rosaceae}

Agrimonia pubescens Wallr. (663)

Agrimonia rostellata Wallr. $(416,589)$

Amelanchier arborea (Michx. f.) Fern. [Amelanchier arborea (Michx. f) Fernald] (144)

Crataegus mollis (T. \& G.) Scheele [Crataegus mollis (Torr. \& A. Gray) Scheele] (790)

Crataegus reverchonii Sarg. var. undetermined (856)

Fragaria virginiana Duchesne (795)

Geum canadense Jacq. var. camporum (Rydb.) Fern. \& Weath. [Geum canadense Jacq.] $(309,596)$

Geum vernum (Raf.) T \& G. [Geum vernum (Raf.) Torr. \& A. Gray] (794)

Prunus americana Marsh. [Prunus americana Marshall] (773)

Prunus angustifolia Marsh. var. undetermined [Prunus angustifolia Marshall var. undetermined] (150)

Prunus gracilis Engelm. \& Gray [Prunus gracilis Engelm. \& A. Gray] (Kelting 1008)

Prunus hortulana Bailey (791)

Prunus mexicana Wats. [Prunus mexicana S. Watson] $(137,140,141,142)$

Prunus serotina Ehrh. $(867,887)$

Rosa arkansana Porter var. suffulta (Greene) Cockerell [Rosa arkansana Porter] (474)

Rosa carolina L. $(288,404,742)$

Rosa setigera Michx. var. tomentosa T. \& G. [Rosa setigera Michx.] (36)

Rubus mollior Bailey [Rubus pensylvanicus Poir.] (868)

Sanguisorba annua Nutt. [Poteridium annuum (Nutt.) Spach.] (287)

\section{Leguminosae [Fabaceae]}

Acacia angustissima (Mill.) Kuntze var. hirta (Nutt.) Robinson (Latting 101)

Amorpha canescens Pursh var. canescens [Amorpha canescens Pursh] (37)

Amorpha canescens Pursh var. glabrata Gray [Amorpha canescens Pursh] (722)

Amorpha fruticosa L. var. fruticosa (448)

Amphicarpa bracteata (L.) Fern. var. bracteata [Amphicarpaea bracteata (L.) Fernald var. bracteata] (658)

Astragalus canadensis L. (470)

Astragalus caryocarpus Ker [Astragalus carassicarpus Nutt. var. crassicarpus] (297)

Astragalus nuttallianus DC. var. nuttallianus [Astragalus nuttallianus DC.] (286) 
Baptisia leucantha T. \& G. [Baptisia lactea (Raf.) Thieret var. lactea] (41)

Baptisia leucophaea Nutt. var. leucophaea [Baptisia leucophaea Nutt.] (859)

Baptisia minor Lehm. [Baptisia australis (L.) R. Br. var. minor (Lehm.) Fernald] (255)

Cassia fasciculata Michx. [Chamaecrista fasciculata (Michx.) Greene var. fasciculata] $(362,426)$

Cassia marilandica L. [Senna marilandica (L.) Link.] (526)

Cassia nictitans L. [Chamaecrista nictitans (L.) Moench var. nictitans] $(466,595)$

Cercis canadensis L. var. canadensis (786)

Clitoria mariana L. (531)

Crotalaria sagittalis L. (379)

Dalea lanata Spreng. (101)

Desmanthus illinoensis (Michx.) MacM. $(43,400)$

Desmodium canescens (L.) DC. $(523,582,654)$

Desmodium glutinosum (Muhl.) Wood [Desmodium glutinosum (Muhl.) Alph. Wood] (408)

Desmodium illinoense Gray [Desmodium illinoense A. Gray] (407)

Galactia volubilis (L.) Britt. var. mississippiensis Vail [Galactia volubilis (L.) Britton] $(473,533,754)$

Gleditsia triacanthos L. (884)

Glycyrrhiza lepidota (Nutt.) Pursh (478)

Gymnocladus dioica (L.) Koch $(391,759)$

Indigofera leptosepala Nutt. [Indigofera miniata Ortega] (374)

Lathyrus pusillus Ell. [Lathyrus pusillus Elliott] (259)

Lespedeza stuevei Nutt. var. angustifolia Britt. [Lespedeza X neglecta Mack. \& Bush (pro sp.)] $(598,753)$

Lespedeza violacea (L.) Pers. (620)

Medicago hispida Gaertn. [Medicago polymorpha L.] (318)

Medicago sativa L. (465)

Melilotus alba Desv. [Melilotus albus Medik.] (26)

Melilotus officinalis (L.) Lam. (16)

Neptunia lutea (Leavenw.) Benth. (442)

Petalostemum candidum (Willd.) Michx. [Dalea candida Michx. ex Willd.] (38)

Petalostemum multiflorum Nutt. [Dalea multiflora (Nutt.) Shinners] (488)

Petalostemum purpureum (Vent.) Rydb. [Dalea purpurea Vent.] (24)

Prosopis juliflora (Swartz) DC. var. torreyana Benson [Prosopis glandulosa Torr. var. torreyana

(L.D. Benson) M.C. Johnson] $(440,973)$

Psoralea esculenta Pursh [Pediomelum esculentum (Pursh) Rydb.] (294)

Psoralea tenuiflora Pursh [Psoralidium tenuiflorum (Pursh) Rydb.] $(273,337,463)$

Robinia pseudo-acacia L. (860)

Schrankia nuttallii (DC.) Standl. [Mimosa nuttallii (DC. ex Britton \& Rose) B.L. Turner] (7)

Sesbania exaltata (Raf.) Cory [Sesbania herbacea (Mill.) McVaugh] $(89,561,631)$

Strophostyles helvola (L.) Ell. [Strophostyles helvola (L.) Elliott] $(109,475,495)$

Strophostyles leiosperma (T. \& G.) Piper [Strophostyles leiosperma (Torr. \& A. Gray) Piper] $(108,468)$

Stylosanthes biflora (L.) BSP. var. hispidissima (Michx.) Pollard \& Ball [Stylosanthes biflora (L.) Britton,

Sterns \& Poggenb.] (46)

Tephrosia virginiana (L.) Pers. var. holosericea (Nutt.) T. \& G. [Tephrosia virginiana (L.) Pers. var.

holosericea (Nutt.) Torr. \& A. Gray] (22)

Trifolium repens L. (735)

Vicia micrantha Nutt. [Vicia minutiflora D. Dietr.] (780)

Vicia villosa Roth. (300) 


\section{Linaceae}

Linum lewisii Pursh var. pratense Norton [Linum pratense (Norton) Small] $(217,346)$

Linum medium (Planch.) Britton var. texanum (Planch.) Fern. [Linum medium (Planch.) Britton var. texanum (Planch.) Fernald] (328)

Linum sulcatum Riddell $(45,298,423)$

\section{Oxalidaceae}

Oxalis europaea Jord. var. europaea [Oxalis stricta L.] (690)

Oxalis stricta L. (483)

Oxalis violacea L. var. violacea [Oxalis violacea L.] (4)

\section{Geraniaceae}

Geranium carolinianum L. (19)

\section{Zygophyllaceae}

Kallstroemia intermedia Rydb. [Kallstroemia parviflora Norton] (116)

Tribulus terrestris L. (39)

\section{Rutaceae}

Xanthoxylum americanum Mill. [Zanthoxylum americanum Mill.] (145)

\section{Simaroubaceae}

Ailanthus altissima (Mill.) Swingle (Kelting 1050)

\section{Polygalaceae}

Polygala incarnata L. $(301,348,406)$

\section{Euphorbiaceae}

Acalypha gracilens Gray var. gracilens [Acalypha gracilens A. Gray] (86)

Acalypha ostryaefolia Riddell [Acalypha ostryifolia Riddell] $(87,492)$

Acalypha rhomboidea Raf. (493)

Acalypha virginica L. (312)

Cnidoscolus texanus (Muell. Arg.) Small (361)

Croton capitatus Michx. (93)

Croton glandulosus L. var. septentrionalis Muell. Arg. [Croton glandulosus L.] $(78,487)$

Croton monanthogynus Michx.

Crotonopsis linearis Michx. [Croton michauxii G.L. Webster] (464)

Euphorbia chamaesyce L. [A misidentification, as this species does not occur in North America.] (119)

Euphorbia corollata L. var. corollata [Euphorbia corollata L.] $(82,405)$

Euphorbia dentata Michx. $(60,73,447)$

Euphorbia dictyosperma Fisch. \& Mey. [Euphorbia spathulata Lam.] (262)

Euphorbia heterophylla L. $(411,550)$

Euphorbia hexagona Nutt. [Euphorbia hexagona Nutt. ex Spreng.] $(103,686)$

Euphorbia maculata L. (83)

Euphorbia marginata Pursh (608)

Euphorbia missurica Raf. var. calcicola (Shinners) Waterfall [Euphorbia missurica Raf.] $(99,120,565)$

Euphorbia serpens HBK. [Euphorbia serpens Kunth] $(104,684)$ 
Euphorbia supina Raf. [Euphorbia maculata L.] $(77,105)$

Stillingia sylvatica L. (276)

Tragia urticifolia Michx. (14)

\section{Callitrichaceae [Plantaginaceae]}

Callitriche heterophylla Pursh (Kelting 997)

\section{Anacardiaceae}

Cotinus obovatus Raf. $(239,881,882)$

Rhus aromatica Ait. var. undetermined (136)

Rhus aromatica Ait. var. aromatica (743)

Rhus copallina L. var. latifolia Engler [Rhus copallinum L. var. copallinum]

Rhus glabra L. (314)

Rhus radicans L. [Toxicodendron radicans (L.) Kuntze ssp. radicans] (observed)

Rhus toxicodendron L. [Toxicodendron pubescens Mill.] (observed)

Aguifoliaceae [Aquifoliaceae]

Ilex decidua Walt. [llex decidua Walter] $(193,223)$

\section{Celastraceae}

Celastrus scandens L. $(415,699)$

Euonymus atropurpureus Jacq. (436)

\section{Staphyleaceae}

Staphylea trifolia L. (203)

Aceraceae [Sapindaceae]

Acer negundo L. var. negundo (143)

Acer saccharinum L. (774)

Hippocastanaceae [Sapindaceae]

Aesculus glabra Willd. var. sargentii Rehd. [Aesculus glabra Willd. var. glabra] (185)

\section{Sapindaceae}

Sapindus drummondi H. \& A. [Sapindus saponaria L. var. drummondii (Hook. \& Arn.) L.D. Benson] (726) Cardiospermum halicacabum L. $(580,751)$

\section{Balsaminaceae}

Impatiens capensis Meerburg [Impatiens capensis Meerb.] (432)

\section{Rhamnaceae}

Ceanothus americanus L. var. pitcheri T. \& G. [Ceanothus americanus L. var. pitcheri Torr. \& A. Gray] (69)

\section{Vitaceae}

Ampelopsis arborea (L.) Koehne (585)

Ampelopsis cordata Michx. $(438,563)$

Cissus incisa (Nutt.) Des Moulins [Cissus trifoliatus (L.) L.] $(500,547)$ 
Parthenocissus quinquefolia (L.) Planch. (876)

Vitis aestivalis Michx. var. argentifolia (Munson) Fern. [Vitis aestivalis Michx. var. bicolor Deam] (250)

Vitis vulpina L. (870)

\section{Malvaceae}

Abutilon theophrasti Medic. (634)

Callirhoe alceoides (Michx.) Gray [Callirhoe alcaeoides (Michx.) A. Gray] (233)

Callirhoe involucrata (T. \& G.) Gray var. involucrata [Callirhoe involucrata (Torr. \& A. Gray) A. Gray var. involucrata] (59)

Hibiscus lasiocarpos Cav. [Hibiscus moscheutos L. spp. lasiocarpos (Cav.) O.J. Blanch.] (579)

Hibiscus militaris Cav. [Hibiscus laevis All.] (522)

Sida spinosa L. (517)

Sphaeralcea angusta (Gray) Fern. [Malvastrum hispidum (Pursh) Hochr.] $(380,424)$

\section{Guttiferae [Hypericaceae]}

Ascyrum hypericoides L. var. multicaule (Michx.) Fern. [Hypericum hypericoides (L.) Crantz ssp. multicaule (Michx. ex Willd.) N. Robson] (467)

Hypericum drummondii (Grev. \& Hook.) T. \& G. [Hypericum drummondii (Grev. \& Hook) Torr. \& A. Gray] $(472,494,502)$

Hypericum gymnanthum Engelm. \& Gray [Hypericum gymnathum Engelm. \& A. Gray] (670)

Hypericum sphaerocarpum Michx. $(31,381)$

\section{Tamaricaceae}

Tamarix gallica L. (98)

\section{Cistaceae}

Lechea tenuifolia Michx. var. tenuifolia [Lechea tenuifolia Michx.] (329)

\section{Violaceae}

Hybanthus linearis (Torr.) Shinners [Hybanthus verticillatus (Ortega) Baill.] (281)

Viola kitaibeliana R. \& S. var. rafinesquii (Greene) Fern. [Viola bicolor Pursh] (151)

Viola missouriensis Greene [Viola sororia Willd. var. missouriensis (Greene) L.E. McKinney] $(152,153,793)$

Viola pensylvanica Michx. var. pensylvanica [Viola pubescens Aiton var. scabriuscula Torr. \& A. Gray] (771)

Viola pensylvanica Michx. var. leicarpa (Fern. \& Wieg.) Fern. [Viola pubescens Aiton var. scabriuscula Torr. \& A. Gray] (182)

Viola sororia Willd. [Viola sororia Willd. var. sororia] (770)

Viola triloba Schwein var. dilatata (Ell.) Brainerd [Viola palmata L.] (197)

\section{Passifloraceae}

Passiflora incarnata L. $(51,528)$

Passiflora lutea L. var. glabriflora Fern. [Passiflora lutea L.] $(549,560)$

\section{Loasaceae}

Mentzelia oligosperma Nutt. [Mentzelia oligosperma Nutt. ex Sims] $(334,571)$ 


\section{Cactaceae}

Neobessya similis (Engelm.) Br. \& Rose [Escobaria missouriensis (Sweet) D.R. Hunt var. missouriensis] (observed)

Opuntia macrorhiza Engelm. (742A)

\section{Lythraceae}

Ammannia auriculata Willd. $(81,421)$

Ammannia coccinea Rothb. (703A)

Cuphea petiolata (L.) Koehne [Cuphea viscocissima Jacq.] (600)

Lythrum lanceolatum Ell. [Lythrum alatum Pursh var. lanceolatum (Elliott) Torr. \& A. Gray ex Rothr.] $(62,358,377)$

Rotala ramosior (L.) Koehne var. interior Fern. \& Grisc. [Rotala ramosior (L.) Koehne] (552)

\section{Onagraceae}

Gaura biennis L. var. pitcheri Pickering [Oenothera filiformis (Small) W.L. Wagner \& Hoch] $(74,497$, $545,640)$

Gaura parviflora Dougl. [Oenothera curtiflora W.L. Wagner \& Hoch] (484)

Gaura suffulta Engelm. [Oenothera suffulta (Wngelm.) W. L. Wagner \& Hoch] $(254,382)$

Gaura tripetala Cav. var. triangulata (Buckl.) Munz. [Oenothera triangulata (Buckley) W.L. Wagner \& Hoch] $(339,383)$

Jussiaea decurrens (Walt.) DC. [Ludwigia decurrens (DC.) Walter] (581)

Jussiaea repens L. var. glabrescens Ktze. [Ludwigia peploides (Kunth) P.H. Raven ssp. glabrescens (Kuntze) P.H. Raven] $(55,388,534)$

Ludwigia alternifolia L. $(490,577,614)$

Ludwigia palustris (L.) Ell. var. americana (DC.) Fern. \& Grisc. [Ludwigia palustris (L.) Elliott] $(434,573)$

Oenothera biennis L. var. canescens T. \& G. [Oenothera villosa Thunb. ssp. villosa] (618)

Oenothera biennis L. var. hirsutissima Gray [Oenothera elata Kunth. ssp. hirsutissima (A. Gray ex

S. Watson) W. Dietr.] (601)

Oenothera laciniata Hill var. laciniata [Oenothera laciniata Hill] (278)

Oenothera linifolia Nutt. (242)

Oenothera rhombipetala Nutt. [Oenothera rhombipetala Nutt. ex Torr. \& A. Gray] (360)

Oenothera serrulata Nutt. $(265,279)$

Oenothera speciosa Nutt. (285)

Oenothera triloba Nutt. $(187,210)$

\section{Umbelliferae [Apiaceae]}

Ammoselinum butleri (Engelm.) Coult. \& Rose [Ammoselinum butleri (Engelm. ex S. Watson)

J.M. Coult. \& Rose] (820)

Bifora americana (DC.) Wats [Bifora americana Benth. \& Hook. f. ex S. Watson] $(290,338)$

Chaerophyllum texanum C. \& R. [Chaerophyllum tainturieri Hook. var. tainturieri] (200)

Cicuta maculata L. (530)

Cynosciadium pinnatum DC. [Limnosciadium pinnatum (DC.) Mathias \& Constance] (295)

Daucus pusillus Michx. (418)

Eryngium leavenworthii T. \& G. [Eryngium leavenworthii Torr. \& A. Gray] (121)

Eryngium yuccifolium Michx. var. synchaetum Gray [Eryngium yuccifolium Michx. var. synchaetum

A. Gray ex J.M. Coult. \& Rose] (357) 
Lomatium foeniculaceum (Nutt.) Coulter \& Rose [Lomatium foeniculaceum (Nutt.) J.M. Coulter \& Rose] $(128,162)$

Polytaenia nuttallii DC. var. nuttallii [Polytaenia nuttallii DC.] (34)

Ptilimnium nuttallii (DC.) Britton (44, 389)

Sanicula canadensis L. var. canadensis $(308,444)$

Sanicula gregaria Bicknell [Sanicula odorata (Raf.) K.M. Pryer \& L.R. Phillippe] (253)

Spermolepis echinata (Nutt.) Heller [Spermolepis echinata (Nutt. ex DC.) A. Heller] (325)

Torilis japonicus (Houtt.) DC. [Torilis japonica (Houtt.) DC.] $(67,417)$

Zizia aurea (L.) Koch $(222,461)$

\section{Cornaceae}

Cornus drummondii Meyer (271)

\section{Ericaceae}

Vaccinium arboreum Marsh. var. arboreum [Vaccinium arboreum Marsh] (719)

\section{Primulaceae}

Androsace occidentalis Pursh (159)

Centunculus minimus L. [Anagallis minima (L.) E.H.L. Krause] (323)

Dodecatheon meadia L. [Primula meadia (L.) A.R. Mast \& Reveal] $(176,251,252)$

Lysimachia ciliata L. (433)

Samolus parviflorus Raf. [Samolus valerandi L.] (Kelting 1009)

\section{Sapotaceae}

Bumelia lanuginosa (Michx.) Pers. var. oblongifolia (Nutt.) R.B. Clark [Sideroxylon lanuginosum Michx. var. oblongifolium (Nutt.) T.D. Penn] (446)

\section{Ebenaceae}

Diospyros virginiana L. var. virginiana [Diospyros virginiana L.] (905)

Diospyros virginiana L. var. undetermined [Diospyros virginiana L.] (741)

\section{Oleaceae}

Forestiera acuminata (Michx.) Poir. (777)

Fraxinus americana L. (157)

Fraxinus pennsylvanica Marsh. var. subintegerrima [Fraxinus pennsylvanica Marshall] $(195,878)$

Fraxinus quadrangulata Michx. (139)

\section{Gentianaceae}

Sabatia campestris Nutt. $(347,354,399)$

\section{Apocynaceae}

Apocynum cannabinum L. var. cannabinum [Apocynum cannabinum L.] (739)

\section{Asclepiadaceae [Apocynaceae]}

Ampelamus albidus (Nutt.) Britt. [Cynanchum laeve (Michx.) Pers.] (485)

Asclepiadora viridis (Walt.) Gray [Asclepias viridis Walter] (33)

Asclepias amplexicaulis J.E. Smith $(70,419)$ 
Asclepias auriculata (Engelm.) Holz. [Asclepias engelmanniana Woodson] (320) [Probably

misidentified; this species does not occur in eastern Oklahoma.]

Asclepias hirtella (Pennell) Woodson (639)

Asclepias incarnata L. (564)

Asclepias speciosa Torr. (972)

Asclepias stenophylla Gray [Asclepias stenophylla A. Gray] $(42,398)$

Asclepias tuberosa L. (21)

Asclepias verticillata L. $(40,586)$

Asclepias viridiflora Raf. var. viridiflora [Asclepias viridiflora Raf.] $(29,403)$

Gonolobus gonocarpus (Walt.) Perry [Gonolobus suberosus (L.) R.Br. var. suberosus] $(58,597)$

\section{Convolvulaceae}

Convolvulus arvensis L. (370)

Cuscuta cuspidata Engelm. (982)

Cuscuta gronovii Willd. (652)

Ipomea hederacea (L.) Jacq. var. integriscula Gray [lpomoea hederacea Jacq.] (617)

Ipomea lacunosa L. [Ipomoea lacunosa L.] (610)

Ipomea pandurata (L.) G.F.W. Mey. [Ipomoea pandurata (L.) G.F.W. Mey.] (457)

\section{Polemoniaceae}

Phlox divaricata L. var. laphamii Wood [Phlox divaricata L. ssp. laphamii (Alph. Wood) Wherry] (206)

Phlox pilosa L. var. ozarkana Wherry [Phlox pilosa L. ssp. ozarkana (Wherry) Wherry] $(10,270)$

\section{Hydrophyllaceae}

Ellisia nyctelea L. (205)

Nama hispidum Gray [Nama hispida A. Gray] [Boraginaceae] (283)

Phacelia gilioides A. Brand (220)

Phacelia hirsuta Nutt. (211)

\section{Boraginaceae}

Heliotropium curassavicum L. (97)

Heliotropium indicum L. (385)

Heliotropium tenellum (Nutt.) Torr. $(282,336)$

Lithospermum arvense L. [Buglossoides arvensis (L.) I.M. Johnst.] (169)

Lithospermum incisum Lehm. (171)

Myosotis verna Nutt. $(196,235)$

Onosmodium hispidissimum Mackenzie [Onosmodium bejariense DC. ex A. DC. var hispidissimum

(Mack.) B.L. Turner] (310)

\section{Verbenaceae}

Lippia lanceolata Michx. var. recognita Fern. \& Grisc. [Phyla lanceolata (Michx.) Greene] (66)

Lippia nodiflora (L.) Michx. [Phyla nodiflora (L.) Greene] (306)

Verbena bracteata Lag. \& Rodr. [Verbena bracteata Cav. ex Lag. \& Rodr.] (363)

Verbena canadensis (L.) Britt. [Glandularia canadensis (L.) Nutt.] $(72,425)$

Verbena simplex Lehm. (342)

Verbena stricta Vent. (366)

Verbena urticifolia L. var. urticifolia $(64,441,524)$ 


\section{Labiatae [Lamiaceae]}

Agastache nepetoides (L.) Kuntze (698)

Hedeoma hispida Pursh (261)

Isanthus brachiatus (L.) BSP. [Trichostema brachiatum L.] (569)

Lamium amplexicaule L. (184)

Monarda citriodora Cerv. [Monarda citriodora Cerv. ex Lag.(291)

Monarda fistulosa L. var. mollis (L.) Benth. (352)

Physostegia angustifolia Fern. [Physostegia angustifolia Fernald] $(47,349)$

Prunella vulgaris L. var. lanceolata (Bart.) Fern. [Prunella vulgaris L. ssp. lanceolata (W. Bartram) Hultén] (396)

Pycnanthemum tenuifolium Schrad. (469)

Salvia azurea Lam. var. grandiflora Benth. (529)

Satureja arkansana (Nutt.) Brig. [Clinopodium glabrum (Nutt.) Kuntze] (292)

Scutellaria lateriflora L. $(307,413)$

Scutellaria parvula Michx. var. parvula $(18,246)$

Stachys tenuifolia Willd. $(599,660)$

Teucrium canadense L. var. virginicum (L.) Eat. [Teucrium canadense L. var. canadense] (367)

\section{Solanaceae}

Datura stramonium L. $(35,612)$

Physalis pendula Rydb. [Physalis angulata L.] (395)

Physalis pubescens L. (392)

Physalis pumila Nutt. (8)

Physalis subglabrata Mackenz. \& Bush [Physalis longifolia Nutt. var. subglabrata (Mack. \& Bush.) Cronquist] (638)

Solanum americanum Mill. (409)

Solanum carolinese L. [Solanum carolinense L.] $(744,976)$

Solanum elaeagnifolium Cav. (333)

Solanum rostratum Dunal $(123,747)$

\section{Scrophulariaceae}

Buchnera americana L. [Orobanchaceae] (428)

Castilleja purpurea (Nutt.) G. Don [Orobanchaceae] $(230,244)$

Collinsia violacea Nutt. [Plantaginaceae] (179)

Conobea multifida (Michx.) Benth. [Leucospora multifida (Michx.) Nutt.] [Plantaginaceae] (378)

Gerardia grandiflora Benth. var. cinerea (Pennell) Cory [Aureolaria grandiflora (Benth.) Pennell]

[Orobanchaceae] $(501,535,680)$

Gerardia heterophylla Nutt. [Agalinis heterophylla (Nutt.) Small] [Orobanchaceae] $(88,630,647)$

Gerardia skinneriana Wood [Agalinis skinneriana (Alph. Wood) Britton] [Orobanchaceae] $(678,717)$

Linaria canadensis (L.) Dumont var. texana Pennell [Nuttallanthus texanus (Scheele) D.A. Sutton]

[Orobanchaceae] (218)

Lindernia anagallidea (Michx.) Pennell [Lindernia dubia (L.) Pennell] [Linderniaceae] $(386,420)$

Mimulus alatus Ait. [Phrymaceae] $(575,609)$

Penstemon cobaea Nutt. [Plantaginaceae] (267)

Penstemon tubaeflorus Nutt. [Plantaginaceae] $(275,313,504)$

Seymeria macrophylla Nutt. [Dasistoma macrophylla (Nutt.) Raf.] [Orobanchaceae] (435)

Verbascum thapsus L. (477) 
Veronica arvensis L. [Plantaginaceae] (180)

Veronica hederaefolia L. [Veronica hederifolia L.] [Plantaginaceae] $(132,134,175,864)$

Veronica peregrina L. var. peregrina [Veronica peregrina L.] [Plantaginaceae] (198)

Veronica peregrina L. var. xalapensis (HBK.) St. John \& Warren [Veronica peregrina L.]

[Plantaginaceae] $(202,796)$

Veronica polita Fries [Plantaginaceae] $(126,133)$

\section{Bignoniaceae}

Campsis radicans (L.) Seem. [Campsis radicans (L.) Seem. ex Bureau] (365)

Catalpa speciosa Warder [Catalpa speciosa (Warder) Warder ex Engelm.] (904)

\section{Lentibulariaceae}

Utricularia biflora Lam. [Utricularia gibba L.] (115)

\section{Acanthaceae}

Dicliptera brachiata (Pursh) Spreng. (544)

Justicia americana (L.) Vahl var. subcoriacea Fern. [Justicia americana (L.) Vahl] $(56,350)$

Ruellia humilis Nutt. var. humilis [Ruellia humilis Nutt.] (5)

Ruellia humilis Nutt. var. longiflora (Gray) Fern. [Ruellia humilis Nutt.] (376)

Ruellia strepens L. $(20,594)$

\section{Phrymaceae}

Phryma leptostachya L. (555)

\section{Plantaginaceae}

Plantago aristata Michx. $(13,304,341,351)$

Plantago purshii R. \& S. var. purshii [Plantago patagonica Jacq.] $(30,340)$

Plantago pusilla Nutt. (191)

Plantago rugelii Dcne. [Plantago rugelii Decne.] $(412,505)$

Plantago virginica L. (263)

\section{Rubiaceae}

Cephalanthus occidentalis L. var. occidentalis [Cephalanthus occidentalis L.] (63)

Diodia teres Walt. var. setifera Fern. \& Grisc. [Diodia teres (Walter) Small] $(114,371)$

Galium aparine L. (213)

Galium pilosum Ait. var. puncticulosum (Michx.) T. \& G. [Galium pilosum Aiton var. puncticulosum

(Michx.) Torr. \& A. Gray] (327)

Galium virgatum Nutt. (234)

Houstonia minima Beck [Houstonia pusilla Schoepf] (149)

Houstonia nigricans (Lam.) Fern. [Stenaria nigricans (Lam.) Terrell var. nigricans] (266)

Spermacoce glabra Michx. (525)

\section{Caprifoliaceae}

Lonicera flava Sims (192)

Sambucus canadensis L. var. canadensis [Sambucus nigra L. ssp. canadensis (L.) R. Bolli]

[Adoxaceae] (364)

Symphoricarpos orbiculatus Moench (393)

Viburnum rufidulum Raf. [Adoxaceae] (238) 


\section{Valerianaceae}

Valerianella radiata (L.) Durf. var. radiata [Valerianella radiata (L.) Dufr.] $(12,862)$

\section{Cucurbitaceae}

Cucurbita foetidissima HBK. [Cucurbita foetidissima Kunth] (343)

Melothria pendula L. $(512,557)$

Sicyos angulatus L. (651)

\section{Campanulaceae}

Campanula americana L. var. illinoensis (Fresn.) Farw. [Campanula americana L.] $(553,632)$

Lobelia appendiculata DC. (356)

Lobelia puberula Michx. var. mineolana E. Wimm. (672)

Lobelia spicata Lam. var. leptostachys (A. DC.) Mack. \& Bush [Lobelia spicata Lam.] (299)

Specularia biflora (R. \& P.) Fisch. \& Mey. [Triodanis perfoliata (L.) Nieuwl. ssp. biflora (Ruiz \& Pav.)

Lammers] (305)

Specularia leptocarpa (Nutt.) Gray [Triodanis leptocarpa (Nutt.) Nieuwl.] (284)

Specularia perfoliata (L.) A. DC. [Triodanis perfoliata (L.) Niewl. ssp. perfoliata] $(17,274)$

\section{Compositae [Asteraceae]}

Achillea lanulosa Nutt. [Achillea millefolium L.] (3)

Actinomeris alternifolia (L.) DC. [Verbesina alternifolia (L.) Britton ex Kearney] (558)

Ambrosia artemisiifolia L. var. elatior (L.) Descourtils [Ambrosia artemisiifolia L.] $(118,704)$

Ambrosia trifida L. var. texana Scheele [Ambrosia trifida L.] $(683,746)$

Antennaria campestris Rydb. [Antennaria neglecta Greene] (776)

Antennaria plantaginifolia (L.) Richards (177)

Aphanostephus skirrobasis (DC.) Trel. (368)

Artemisia caudata Michx. [Artemisia campestris L. ssp. caudata (Michx.) H.M. Hall \& Clem.] (Miller unnumbered) [Probably a misidentification, as this species does not occur in Oklahoma.]

Artemisia ludoviciana Nutt. var. mexicana (Willd.) Fern. [Artemisia ludoviciana Nutt. ssp. mexicana

(Willd. ex Spreng.) D.D. Keck] $(90,691,745)$

Aster ericoides L. [Symphyotrichum ericoides (L.) G.L. Nesom] $(695,702)$

Aster exilis Ell. [Symphyotrichum subulatum (Michx.) G.L. Nesom var. ligulatum (Shinners) S.D.

Sundb.] $(75,76,622,677)$

Aster oblongifolius Nutt. [Symphyotrichum oblongifolium (Nutt.) G.L. Nesom] (701)

Aster ontarionis Wieg. [Symphyotrichum ontarionis (Wiegand) G.L. Nesom] (716A, 716B)

Aster patens Ait. var. gracilis Hook [Symphyotrichum patens (Aiton) G.L. Nesom var. gracile (Hook.)

G.L. Nesom] (676, 716C, 716D)

Aster praealtus Poir. [Symphyotrichum praealtum (Poir.) G.L. Nesom] $(708,709,710,713)$

Aster sagittifolius Wedemeyer var. drummondii (Lindl.) Shinners [Symphyotrichum drummondii (Lindl.)

G.L. Nesom var. drummondii] $(697,711)$

Aster simplex Willd. [Symphyotrichum lanceolatum (Willd.) G.L. Newsom var. lanceolatum] (730)

Aster vimineus Lam. var. subdumosus Wieg. [Symphyotrichum racemosum (Elliot) G.L. Newsom] (755)

Astranthium integrifolium (Michx.) Nutt. var. undetermined $(1,2)$

Bidens bipinnata L. (615)

Bidens frondosa L. (650)

Bidens polylepis Blake (646)

Boltonia latisquama Gray [Boltonia asteroides (L.) L'Hér. var. latisquama (A. Gray) Cronquist] $(506,635)$ 
Cacalia plantaginea (Raf.) Shinners [Arnoglossum plantagineum Raf.] (48)

Centaurea americana Nutt. [Plectocephalus americanus (Nutt.) D. Don] (344)

Chrysopsis pilosa Nutt. [Bradburia pilosa (Nutt.) Semple] (277)

Cichorium intybus L. (427)

Cirsium discolor (Muhl.) Spreng. (518)

Cirsium undulatum (Nutt.) Spreng. (974)

Coreopsis grandiflora Hogg. var. grandiflora (Coreopsis grandiflora Hogg ex Sweet.] (264)

Coreopsis tinctoria Nutt. (61)

Echinacea pallida Nutt. (269)

Eclipta alba (L.) Hassk. [Eclipta prostrata (L.) L.] (443)

Elephantopus carolinianus Willd. [Elephantopus carolinianus Raeusch.] $(556,606)$

Erigeron annuus (L.) Pers. $(591,694)$

Erigeron canadensis L. [Conyza canadensis (L.) Cronquist] (79)

Erigeron philadelphicus L. (861)

Erigeron strigosus Muhl. var. strigosus (Erigeron strigosus Muhl. ex Willd. var. strigosus] $(6,32,588)$

Erigeron strigosus Muhl. var. beyrichii (Fisch. \& Mey.) T. \& G. [Erigeron strigosus Muhl. ex Willd. var.

strigosus] (303)

Erigeron tenuis T. \& G. [Erigeron tenuis Torr. \& A. Gray] (256)

Eupatorium coelestinum L. [Conoclinium coelestinum (L.) DC.] (659)

Eupatorium purpureum L. [Eutrochium purpureum (L.) E.E. Lamont] (668)

Eupatorium rugosum Houtt. var. undetermined [Ageratina altissima (L.) King \& H. Rob. var. altissima] (655)

Eupatorium serotinum Michx. $(80,604)$

Evax prolifera Nutt. [Diaperia prolifera (Nutt. ex DC.) Nutt.] $(877,907)$

Gaillardia pulchella Foug. (28)

Gnaphalium obtusifolium L. [Pseudognaphalium obtusifolium (L.) Hilliard \& B.L. Burtt] (673)

Gnaphalium purpureum L. [Gamochaeta purpurea (L.) Cabrera] (326)

Grindelia lanceolata Nutt. var. lanceolata [Grindelia lanceolata Nutt.] $(489,703)$

Grindelia squarrosa (Pursh) Dunal var. squarrosa [Grindelia squarrosa (Pursh) Dunal] (122)

Gutierrezia dracunculoides (DC.) Blake [Amphiachyris dracunculoides (DC.) Nutt.]

Happlopappus ciliatus (Nutt.) DC. [Grindelia ciliata (Nutt.) Spreng.] (693)

Happlopappus divaricatus (Nutt.) Gray [Croptilon divaricatum (Nutt.) Raf.] (476)

Helenium tenuifolium Nutt. [Helenium amarum (Raf.) H. Rock var. amarum] (696)

Helianthus annuus L. $(451,566)$

Helianthus besseyi Bates [Helianthus tuberosus L.] $(510,521,623)$

Helianthus hirsutus Raf. var. hirsutus (322)

Helianthus hirsutus Raf. var. trachyphyllus T. \& G. [Helianthus hirsutus Raf. var. trachyphyllus Torr. \&

A. Gray] $(546,587,590)$

Helianthus laetiflorus Pers. var. rigidus (Cass.) Fern. [Helianthus pauciflorus Nutt. var. pauciflorus] (430)

Helianthus maximiliani Schrad. (642)

Helianthus mollis Lam. (431)

Helianthus petiolaris Nutt. (499)

Heliopsis helianthoides (L.) Sweet var. scabra (Dunal) Fern. [Heliopsis helianthoides (L.) Sweet var. scabra (Dunal) Fernald] (583)

Heterotheca subaxillaris (Lam.) Britt. \& Rusby [Heterotheca subaxillaris (Lam.) Britton \& Rusby] $(106,592)$ Hieracium gronovii L. var. undetermined (319)

Hieracium longipilum Torr. (422) 
Hymenopappus corymbosus T. \& G. [Hymenopappus scabiosaeus L'Hér. var. corymbosus (Torr. \& A. Gray) B.L. Turner] (9)

Iva ciliata Willd. [Iva annua L.] $(112,644)$

Krigia dandelion (L.) Nutt. (872)

Kuhnia eupatorioides L. var. corymbulosa T. \& G. [Brickellia eupatorioides (L.) Shinners var. corymbulosa (Torr. \& A. Gray) Shinners] (645)

Lactuca canadensis L. var. latifolia Ktze. [Lactuca canadensis L.] (509)

Lactuca scariola L. [Lactuca serriola L.] (480)

Liatris angustifolia (Bush) Gaiser [Liatris punctata Hook. var. mucronata (DC.) B.L. Turner] (Kelting 861H)

Liatris aspera Michx. var. aspera [Liatris aspera Michx.] (679)

Liatris aspera Michx. var. intermedia (Lunell) Gaiser [Liatris aspera Michx.] (491)

Liatris mucronata DC. [Liatris punctata Hook. var. mucronata (DC.) B.L. Turner] (643)

Liatris pycnostachya Michx. (454)

Liatris squarrosa (L.) Michx. var. glabrata (Rydb.) Gaiser (718)

Pluchea purpurascens (Sw.) DC. [Pluchea odorata (L.) Cass. var. odorata] (111)

Polymnia uvedalia L. var. densipilis Blake [Smallanthus uvedalia (L.) Mack. ex Small] (656)

Pyrrhopappus carolinianus (Walt.) DC. $(335,738)$

Pyrrhopappus scaposus DC. [Pyrrhopappus grandiflorus (Nutt.) Nutt.] $(226,879)$

Ratibida columnifera (Nutt.) W. \& S. [Ratibida columnifera (Nutt.) Woot. \& Standl.] (25)

Rudbeckia amplexicaulis Vahl (57)

Rudbeckia bicolor Nutt. [Rudbeckia hirta L. var. pulcherrima Farw.] $(49,401)$

Rudbeckia triloba L. var. triloba (460)

Senecio aureus L. [Packera aurea (L.) Á. Löve \& D. Löve] (178)

Senecio glabellus Poir. [Packera glabella (Poir.) C. Jeffrey] (221)

Senecio plattensis Nutt. [Packera plattensis (Nutt.) W.A. Weber \& Á. Löve] (229)

Serinia oppositifolia (Raf.) Kuntze [Krigia caespitosa (Raf.) K.L. Chambers] (225)

Silphium asperrimum Hook. [Silphium astericus L. var. astericus] $(402,455)$

Silphium laciniatum L. var. lanciniatum [Silphium laciniatum L.] $(450,567)$

Silphium perfoliatum L. $(520,629,669)$

Solidago altissima L. $(707,736)$

Solidago bootii Hook. [Solidago arguta Aiton var. boottii (Hook.) Palmer \& Steyerm.] (508)

Solidago canadensis L. var. canadensis $(624,712)$

Solidago gigantea Ait. var. leiophylla Fern. [Solidago gigantea Aiton] (511)

Solidago missouriensis Nutt. var. fasciculata Holzinger [Solidago missouriensis Nutt.] $(516,576,603)$

Solidago mollis Bartl. (675)

Solidago petiolaris Ait. var. petiolaris [Solidago petiolaris Aiton] (716E)

Solidago petiolaris Ait. var. wardii (Britt.) Fern. [Solidago petiolaris Aiton] (706)

Solidago rigida L. $(692,740)$

Solidago rugosa Mill. var. celtidifolia (Small) Fern. [Solidago rugosa Mill. ssp. aspera (Aiton) Cronquist] (688)

Sonchus asper (L.) Hill (731)

Taraxacum erythrospermum Andrz. [Taraxacum erythrospermum Andrz. ex Besser] (785)

Taraxacum officinale Weber [Taraxacum officinale F.H. Wigg] (797)

Tragopogon porrifolius L. (888)

Verbesina encelioides (Cav.) B. \& H. var. exauriculata Robins. \& Greenm. [Verbesina encelioides

(Cav.) Benth. \& Hook. f. ex A. Gray] (752)

Verbesina virginica L. (605)

Vernonia baldwinii Torr. var. interior (Small) Schub. [Vernonia baldwinii Torr.] $(84,445,471,507,514)$ 
Vernonia crinita Raf. [Vernonia arkansana DC.] $(94,449,479)$

Xanthium chinense Mill. [Xanthium strumarium L.] (715)

Xanthium italicum Mor. [Xanthium strumarium L.] $(124,681,705,749)$

Xanthium pennsylvanicum Wallr. [Xanthium strumarium L.] $(682,748)$

Maxine B. Clark 